\title{
The Effects of Anticipated Future Investments on Firm Value: Evidence from Mergers and Acquisitions
}

\author{
by \\ Ning Zhang \\ Business Administration \\ Duke University
}

Date:

Approved:

Qi Chen, Supervisor

Frank Ecker

Per Olsson

David Robinson

Katherine Schipper

Dissertation submitted in partial fulfillment of the requirements for the degree of Doctor of Philosophy in Business Administration in the Graduate School of Duke University 
$\underline{\text { ABSTRACT }}$

The Effects of Anticipated Future Investments on Firm Value: Evidence from Mergers and Acquisitions

by

Ning Zhang

Business Administration

Duke University

Date:

Approved:

Qi Chen, Supervisor

Frank Ecker

Per Olsson

David Robinson

Katherine Schipper

An abstract of a dissertation submitted in partial

fulfillment of the requirements for the degree of Doctor of Philosophy in

Business Administration in the Graduate School of Duke University 


\section{Copyright by}

Ning Zhang

2013 


\section{Abstract}

I examine the long-term valuation consequence of over-investment in mergers and acquisitions (M\&As) on acquiring firms through the "anticipation effect," in which forward-looking prices embed investors' expectations about the profitability of firms' future acquisitions. Using a sample of 1,451 firms with past acquisition activities, I find that their market valuations depend on both the profitability of their past acquisitions and their current free cash flow. Specifically, among firms with positive free cash flow, those with the worst history of value-destroying acquisitions experience lower market valuations. Among firms with negative free cash flow, the history of value-destroying acquisitions is not systematically associated with firm value. A significant portion of the discount is from a lower valuation of cash holdings. These findings are consistent with investors forming expectations about the profitability of future possible acquisitions based on the performance outcomes of firms' past acquisitions and value these firms accordingly based on the likelihood of engaging in future acquisitions. They also provide empirical support for using observed market prices to proxy for investors' expectations about firms' future investment opportunities. 


\section{Dedication}

This dissertation is dedicated to my parents Weiying Li and Yusheng Zhang. 


\section{Contents}

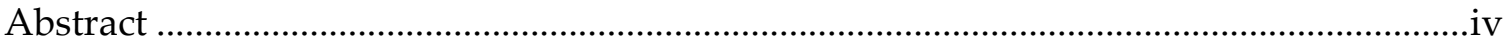

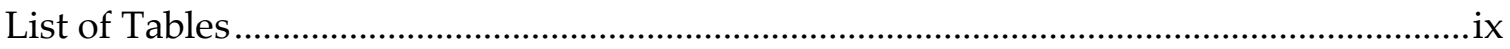

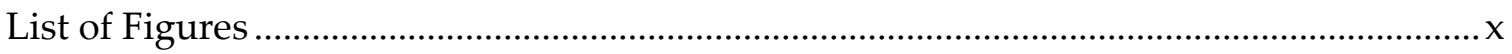

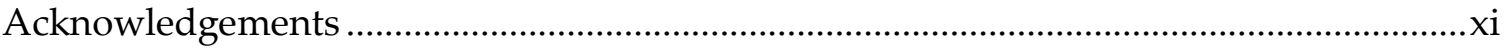

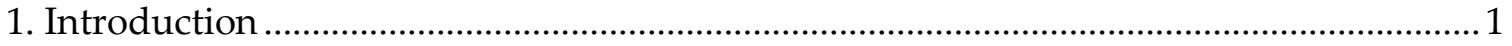

2. Related Literature and Hypothesis Development..........................................................10

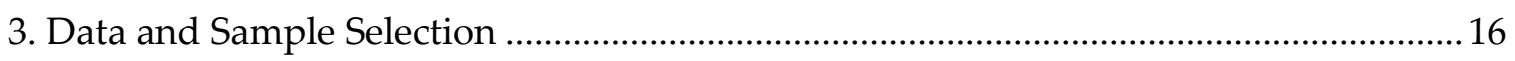

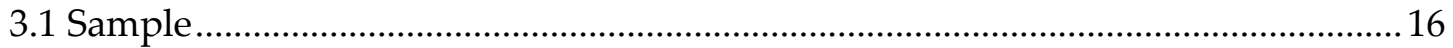

3.2 Main Variable Construction and Summary Statistics .............................................18

4. Main Empirical Analysis..........................................................................................2 26

4.1 Validating the Use of FCF as a Proxy for Future M\&A ...........................................26

4.2 Evidence for the Anticipation Discount ..................................................................2

4.3 Channels of the Discount: Marginal Value of Cash Holdings ....................................38

4.4 Channels of the Discount: Information Uncertainty …………………………….....4 44

4.5 Effect on the Announcement Window Return of Future Acquisitions ...................47

5. Additional Analysis................................................................................................

5.1 Likelihood of Becoming a Target ...........................................................................53

5.2 Further Analysis Using Goodwill Impairment ...........................................................55

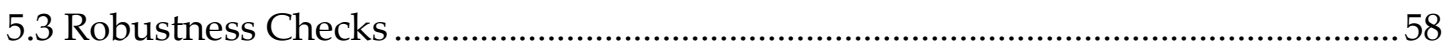

5.3.1 Use Analysts' Forecasted Price to Calculate Tobin's Q ....................................58

5.3.2 Use Alternative Definitions to Calculate BHCAR.............................................6 60

5.3.3 Use Alternative Definitions to Calculate Incidence ...........................................62

5.3.4 Use Alternative Definitions to Classify Acquisitions .........................................64 
5.3.5 Use Alternative Definitions to Classify Likely and Unlikely Acquirers .......6 65

5.3.6 Use Alternative Benchmarks to Subset Prior Acquisitions.............................68

5.3.7 An Examination of Firms Engaging in Multiple Acquisitions .......................69

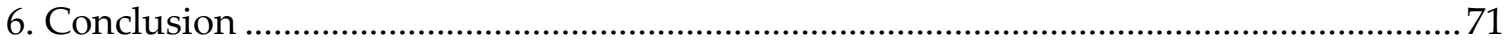

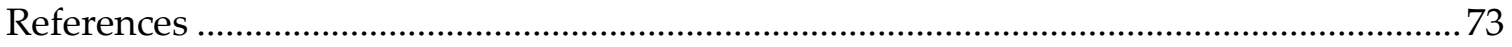

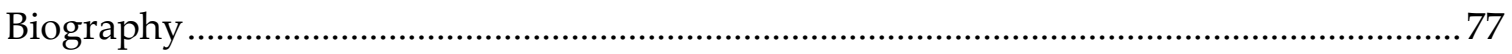




\section{List of Tables}

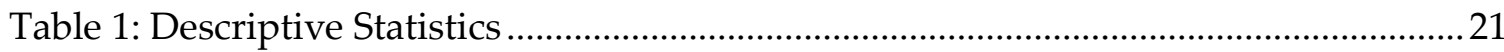

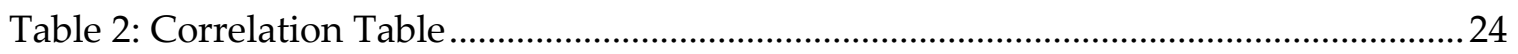

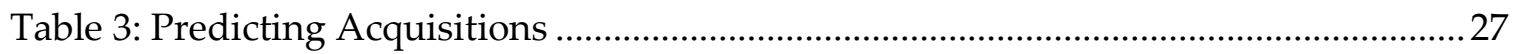

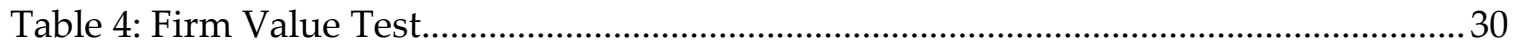

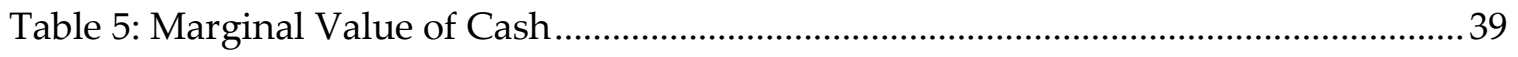

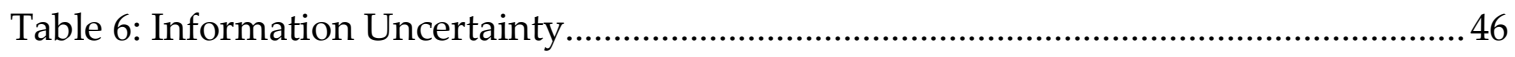

Table 7: Announcement Window Return Test .................................................................. 50

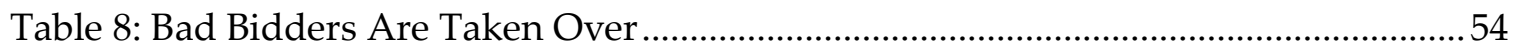

Table 9: Post-2006 Firm Value Test Using Goodwill Impairment.....................................57

Table 10.1: Robustness Check Using Analysts' Forecasted Price......................................59

Table 10.2: Robustness Check Using Alternative BHCAR Definitions ..............................60

Table 10.3: Robustness Check Using Alternative Incidence Definitions............................ 63

Table 10.4: Robustness Check Using ROA to Classify Acquisition Performance..............65

Table 10.5: Robustness Check Using Alternative Ways to Classify Likely and Unlikely

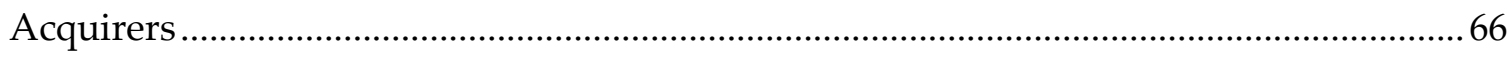

Table 10.6: Robustness Check Using Alternative Benchmarks to Subset Prior

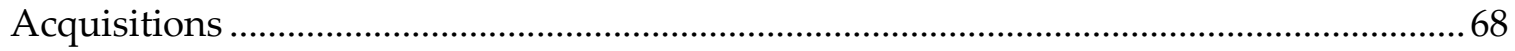

Table 10.7: Results for Firms with Multiple Acquisitions in the Past...............................70 


\section{List of Figures}

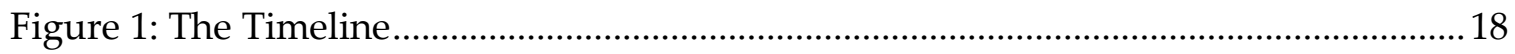




\section{Acknowledgements}

I thank my dissertation committee members for helpful comments and direction. My advisor, Professor Qi Chen, has contributed an immense amount of time, assistance and patience in guiding me towards my goals. None of my work would have been possible without Qi's support. I would also like to thank Professors Katherine Schipper and Per Olsson for their constant encouragement and guidance. I would like to thank Professor Frank Ecker for his assistance with design questions and Professor David Robinson for his inspiration in developing the motivation for my research question. I also appreciate helpful suggestions from Mark Bagnoli, Dirk Black, Peter Chen, Zhenhua Chen, Helen Choy, Steve Fortin, Aloke Ghosh, Zeqiong Huang, Wei Jiang, Yue Li, Carol Marquardt, Lin Nan, Teri Shearer, Steve Salterio, Sheri Tice, Wei Wang, Susan Watts, Mike Welker, Serena $\mathrm{Wu}$, Xuan Tian, Mark Vargus and workshops participants at Baruch College, Drexel University, Duke University, McGill University, Purdue University, Tsinghua University, Tulane University, Queen's University and University of Illinois at Urbana Champaign. Finally, I want to thank my parents for their support. 


\section{Introduction}

Stock prices depend on investors' expectations about firms' future cash flows. As cash flows are generated by investments, it follows that investors' expectations about firms' future investment strategies would play a significant role in affecting stock prices. Indeed, researchers often use firm value as a proxy for investment opportunities (e.g., Lang et al. (1991), Pastor and Veronesi (2003)). The underlying assumption is that stock price embeds investors' expectations about firms' future investment strategies. This paper provides empirical evidence on this assumption, examining the long-term valuation consequences of mergers and acquisitions (M\&As) for acquiring firms. Specifically, I examine whether stock market valuations embed an anticipation discount for acquiring firms that have engaged in value-destroying acquisitions. The idea is that past value-destroying acquisitions lower investors' expectations about the profitability of these firms' future investments through an "anticipation effect," in which forwardlooking firm values contain information about possible upcoming investments in M\&As.

This investigation can also be motivated by anecdotal references in the financial press about the valuation consequences of firms' past M\&A activities. For instance, commenting on Hewlett-Packard's recent low stock price but strong forecasted earnings and growth rate, an analyst at Seeking Alpha wrote, "Companies like Hewlett-Packard (HPQ) may not be good investments for value investors since these companies will continue to pay high valuations for acquisitions." ${ }^{11}$ An implicit assumption underlying this statement is that a firm's past investment history is informative about its future

\footnotetext{
${ }^{1}$ See the full text from Seeking alpha at http://seekingalpha.com/article/262738-glenview-capital-lovesexpedia-and-these-13-super-stocks.
} 
investments. Meanwhile, prior academic research also finds that CEOs play a significant role in investment decisions (Malmendier and Tate (2008)), and that the average CEO tenure is around eight to nine years (Kaplan and Minton (2012)). In addition, it is also possible that managers learn from prior value-destroying acquisitions and in the future invest in value-enhancing acquisitions. To the extent that new CEOs may adopt investment strategies substantially different from those adopted by previous CEOs, or to the extent that managers may learn from their own past investments, it is an empirical question whether and when a firm's past investment history would affect investors' pricing of its future firm value.

I study the valuation implication of investors' expectations about firms' future investment strategies in the context of mergers and acquisitions for several reasons. First, mergers and acquisitions are among firms' largest capital expenditures. Other investments, including R\&D expenditures and purchases of fixed assets, are smaller in magnitude. ${ }^{2}$ Given the large size of M\&A deals, it is important to understand the economic consequence of M\&As not only in the short run but also in the long run. Second, unlike R\&D or purchase of fixed assets, M\&As are discrete investment activities. As documented by Harford and Li (2007), investment through acquisitions is the most readily observed form of corporate empire-building. Existing research (e.g., Rau and Vermaelen (1998) and Bouwman et al. (2009)) has shown that many M\&As result in

2 The mean values of M\&A transaction value and the cash portion of the transaction value in my sample are $\$ 480$ million and $\$ 326$ million, respectively. The Compustat mean values of capital expenditure and R\&D over the same period are $\$ 125$ million and $\$ 63$ million, respectively. 
bidders' post-acquisition stock market underperformance that partially stems from overinvestment due to an agency problem. M\&As thus provide a powerful and representative setting for me to examine the economic consequence of firms' investment strategies. Third, commercially available databases provide exact M\&A transaction details including event dates and transaction values. This allows me to evaluate the outcome of an acquisition after its completion and then use that evaluation as a proxy for future anticipated investment outcomes.

In this paper, I examine the hypothesis that investors form expectations about the profitability of firms' future M\&A investment decisions based on the performance outcomes of past acquisitions and value these firms accordingly based on the likelihood these firms will make future acquisitions. I measure the outcome of an acquisition using the one-year abnormal stock return starting from the completion date of the acquisition. I classify acquisitions with positive one-year post-acquisition abnormal returns as valueenhancing acquisitions and acquisitions with negative one-year post-acquisition abnormal returns as value-destroying acquisitions. I use the firms' free cash flow as a proxy for investors' expectations about the likelihood of future M\&As. In particular, I designate firms as likely acquirers if they have positive free cash flow and as unlikely acquirers if they have negative free cash flow. This designation is motivated by the agency theory that firms tend to overinvest in negative NPV projects when they have positive free cash flow (Jensen (1986)) and empirical findings by Richardson (2006). In 
particular, Richardson finds that firms with positive free cash flow tend to invest beyond the predicted levels.

I find that the market valuations of firms with prior M\&A activities depend on both whether their past M\&As are value-destroying or value-enhancing and whether the firms have positive free cash flow. When firms have positive free cash flow (suggesting that they have the financial means to engage in future M\&As), their valuations are lower if more of their past M\&As are value-destroying. On average, among firms with positive free cash flow, those with the worst history of value-destroying M\&As experience a reduction of $10 \%$ in firm value as measured by Tobin's $Q$, consistent with investors pricing potential future value-destroying acquisitions. ${ }^{3}$ In contrast, among firms with negative free cash flow, the profitability of past M\&As has no significant impact on current market valuations, consistent with the idea that investors assign a low probability to future acquisition activities. These findings are robust to alternative measures of firm value, and to alternative measures of M\&A performance.

I also find that a significant portion of the discount is from discounted valuations of cash holdings. Among firms with positive free cash flow, each additional dollar of cash holdings at firms with the worst history of value-destroying M\&As, on average, is valued 87 cents less than firms whose past M\&As have been most value-enhancing (i.e., more of their M\&As are followed by positive abnormal returns in the year after acquisition completion). This finding is consistent with investors' view that cash will be

\footnotetext{
${ }^{3}$ Throughout this paper, I use "history of value-destroying M\&As" and "history of over-investment" interchangeably.
} 
invested sub-optimally, especially when firms have already made more valuedestroying M\&As.

To further establish that the discount in firm value is related to investors' anticipation of future investments, I examine whether the discount is associated with investor uncertainty about future earnings. I find for firms with positive free cash flow, information uncertainty, proxied by analyst forecast dispersion, is positively associated with the past history of over-investment, consistent with information uncertainty, at least partially, contributing to low firm valuations.

An assumption in my analysis is that investors assess a lower likelihood of future M\&A for firms with negative free cash flow. An implication is that when firms with negative free cash flow actually announce M\&As, the announcements are more likely to be "news" to investors. Consistent with this prediction, I find a significantly higher stock price reaction for acquisition plans made by firms with negative free cash flow. The average 5-day abnormal return around the announcement windows is 0.012 for the negative free cash flow sample and -0.002 for the positive free cash flow sample. Further, for firms with negative free cash flow, the announcement return is negatively associated with past over-investment history, consistent with investors forming expectations about announced acquisitions based on historical realized M\&A performance at the time of acquisition announcements.

This paper contributes to the literature by studying the long-term valuation consequences of acquiring firms' past M\&A activities through the anticipation effect. 
Unlike prior literature that focuses on evaluating whether the merger and acquisition transactions themselves create or destroy values, I emphasize the anticipation effect, a channel through which past M\&As affect investors' expectations about future investments. The findings in this paper have several implications. First, empirical studies often use firm value (e.g., Tobin's Q) as a proxy for firms' investment opportunities (e.g., Lang et al. (1991)). The underlying assumption is that stock prices embed expectations about future investment decisions. My findings provide evidence that validates this assumption. In particular, I argue that the forward-looking firm value contains information about the anticipated M\&As, as well as their anticipated performance.

Second, this research adds capital market consequence to findings in Richardson (2006). Richardson documents that firms are more likely to invest more than expected when they have positive free cash flow. By studying mergers and acquisitions, a specific type of investment, I show that when firms' investment levels are likely to be higher than predicted, investors have typically reacted to this expected increase in investment level according to firms' investment history.

Third, my findings shed light on the underlying mechanism for takeovers to function in a disciplinary role. Mitchell and Lehn (1990) find that firms that made valuedestroying acquisitions ("bad bidders") are more likely to be acquired by other firms as outsiders tend to correct the agency problem manifested in previous bad acquisitions. Their findings suggest that takeovers are both a "symptom" and a "solution" in that 
firms that make value-destroying M\&As exhibit symptoms of over-investment, and the over-investment problems get corrected later when these firms are acquired. The link through which the symptom and the solution are connected, however, is not discussed. My findings shed light on this link. I find that bad bidders experience low firm values in the future when they have positive free cash flow. Thus, the combination of positive free cash flow and low firm value attracts potential buyers to take over the bad bidder in the future. I find that firms with positive free cash flow and histories of value-destroying acquisitions are more likely to be acquired in the future.

This paper extends recent research on the valuation effects of investors' anticipation of pending acquisitions on target firms (Song and Walkling (2000) ${ }^{4}$, Cremers et al. (2008), Edmans et al. (2012)). Cremers et al. (2008) consider the impact of takeover likelihood on target firms' valuation. ${ }^{5}$ They hypothesize and show that firms exposed to takeovers have different returns than protected firms, and a trading strategy of going long (short) firms with high (low) takeover likelihoods creates significant abnormal returns. Edmans et al. (2012) examine target valuation and argue that the observed valuation is the combination of two effects: (1) the trigger effect - a decrease in stock price that invites a takeover attempt; and, (2) the anticipation effect - an increase in stock price due to increased takeover probability. My study differs from theirs in that I focus on the anticipation effect for the acquiring firms. This design has several implications

\footnotetext{
${ }^{4}$ For example, Song and Walkling (2000) develop and test the "Acquisition Probability Hypothesis." They show that rivals of initial acquisition targets earn abnormal returns due to the increased probability that they will be targets themselves.

5 They term takeover likelihood as "takeover vulnerability".
} 
beyond studies on target firms. Specifically, I provide direct evidence on the consequences of firms' investment strategies. In contrast, the anticipation effect for a target firm may come from various sources (e.g., gains from strategic synergy, gains from disciplining target firms) and is unrelated to target firms' investment strategies. In addition, the mechanism of how anticipation works differs for acquiring firms versus target firms. Also unlike Cai et al. (2011) who define anticipated acquirers as later bidders in an industry merger wave, my research motivates the anticipation effect for acquiring firms from agency theory and examines how future firm values are related to inferences from past acquisitions based on the anticipated likelihood of future acquisitions. In other words, I do not study the performance consequences of acquisitions per se; rather, I study the valuation consequences of investors' (revised) expectations about future investments chosen by acquiring firms themselves.

Lastly, this paper adds evidence to the literature examining the value of corporate cash holdings. I document that the anticipated outcome of cash investment measured using realized investment outcomes is directly related to investors' valuation of cash holdings. Analytical models predict that cash assets are prone to the risk that managers direct corporate resources to their own benefits (Myers and Majluf (1984) and Myers and Rajan (1998)). My findings complement their studies by showing that the expectation of this risk affects the valuation of cash assets.

The rest of the paper is organized as follows. The next section reviews related work in this area and develops the hypotheses. Section 3 describes the data and sample 
selection. Section 4 outlines the empirical design and discusses the results. Section 5 presents several additional findings and robustness checks. Section 6 concludes. 


\section{Related Literature and Hypothesis Development}

A large number of studies studying firm performance after mergers and acquisitions finds that while mergers create shareholder value in total, on average, most of the benefits accrue to the target firm (Rau and Vermaelen (1998), Bouwman et al. (2009)).

One explanation for this long-term underperformance is the agency problem between managers and owners. Jensen (1986) posits that managers of firms with positive free cash flow will tend to invest it in wasteful (negative NPV) projects rather than distribute it to shareholders. Lang et al. (1991) find that if investment opportunities are not valued by investors (as evidenced by a low Tobin's $Q$ before the acquisition), the short-window return around the acquisition announcement is inversely related to free cash flow. They interpret this result as suggesting that investors believe that free cash flow encourages over-investment in value-destroying acquisitions. Masulis et al. (2007) find that firms with weak corporate governance experience low announcement returns, consistent with the idea that investors infer that managers in these firms are more likely to make wasteful acquisitions. Richardson (2006) models free cash flow and investment levels simultaneously. ${ }^{1} \mathrm{He}$ estimates firms' predicted levels of investment and shows that firms with positive ex ante free cash flow are more likely to invest at higher than predicted levels. Overall, these studies provide support for the free cash flow hypothesis.

\footnotetext{
${ }^{1}$ As argued in Richardson (2006), the positive relation between observed investment and observed cash flow may due to the fact that cash flow is a proxy for investment opportunities (Alti (2003)). Richardson overcomes this by incorporating accounting-based measures of growth opportunities and simultaneously estimating investment and free cash flow.
} 
A common thread among these previously discussed studies is that researchers conjecture, but do not test directly, that observed stock prices embed expectations about firms' future investment decisions. For example, Lang et al. (1991) classify future M\&As into good and bad investments based on pre-acquisition valuations of acquiring firms, proxied by Tobin's Q. They, do not analyze how expectations about future M\&As are formed. In this paper, I examine the relation between the profitability of firms' past M\&A investment decisions and investors' expectations about the profitability of firms' future M\&A decisions as captured by Tobin's Q. Specifically, I hypothesize that investors expect lower future profitability for firms with more frequent value-destroying M\&A activities in the past and consequently assgin lower values to these firms' stocks. ${ }^{2}$ Since the future profitability is conditional on future M\&A activities, I expect that the lower valuation will be a function of the likelihood that firms engage in M\&A activities in the future. As discussed in detail in Section 3, I proxy for the likelihood of future M\&A activities using a measure of firms' free cash flow (Richardson (2006)). The idea behind this measure is that firms with positive free cash flow are more likely to attempt future M\&As than firms with negative free cash flow. Positive free cash flow firms can fund their investments without accessing external capital markets. To summarize, my first hypothesis in alternative form is stated as follows:

\footnotetext{
2 Throughout this paper, I draw inference about investors' expectations about the profitability of possible future acquisitions based on the valuation difference, i.e., the difference between firms with histories of value-destroying acquisitions versus firms with histories of value-enhancing acquisitions. When having positive free cash flow, firms with more frequent value-destroying acquisitions in the past are hypothesized to have lower firm value compared with firms with more frequent value-enhancing acquisitions in the past.
} 
H1: Firm values are negatively associated with the incidence of past value-destroying M\&As when firms have positive free cash flow.

Since the anticipated over-investment problem is related to cash expenditure, a corollary of $\mathrm{H} 1$ is that the market valuation of cash will depend on investors' assessments of the profitability of future M\&A activities. H1 states that when a firm has positive free cash flow, its value decreases with a worse past investment history. If this relation is caused by investors' anticipation of future investment in a value-destroying M\&A using cash, I expect a lower valuation coefficient on the firm's marginal cash holdings, as cash is more likely to be invested wastefully than to increase shareholder value in these firms. In other words, a low valuation on the firms' marginal cash holdings reflects a discount due to investors' expectation that management will waste cash on hand. In contrast, for firms with negative free cash flow, I do not expect a lower valuation coefficient on marginal cash, as the anticipated likelihood of over-investment is much lower.

Opler et al. (1999) decompose cash holdings into an expected component and an excess component using firm characteristics. The expected component of cash is the amount needed for normal operations, while the excess component is the cash holding beyond what is implied by the business model. As the discount placed by investors is due to investors' expectation of the manager's rent extraction of excess cash, I hypothesize that the discount in the marginal value of cash holdings comes primarily from the excess component. Thus, my second set of hypotheses is stated as follows: 
H2a: The marginal value of cash is negatively associated with the incidence of valuedestroying M\&As for firms with positive free cash flow.

H2b: The marginal value of excess cash is negatively associated with the incidence of value-destroying M\&As for firms with positive free cash flow.

Erickson et al. (2012) find that post-acquisition stock returns are inversely associated with changes in analyst forecast dispersion, their proxy for information uncertainty. They interpret this finding as indicating that information uncertainty is at least a contributing factor to stock price underperformance, as higher information uncertainty leads to a higher discount rate (the denominator effect) for the firm's fundamentals (Wang (1993)). Since H1 and H2 discuss firm value in the context of investors' expectation of future possible acquisitions, I further investigate whether the anticipation effect affects firm values through the discount rate channel. The increase in information uncertainty associated with M\&As may come from both the probability of such an acquisition and the result of combining two separate business entities. To the extent that firms with positive free cash flow are more likely to engage in future M\&As that would significantly alter the scope of their operations, analysts will find it difficult to forecast their future earnings. Firms with histories of value-destroying acquisitions may not carefully select their target firms, resulting in more disagreement in analyst forecasts. Thus, if Erickson et al.'s argument is also valid in anticipating possible acquisitions, information uncertainty, proxied by analyst forecast dispersion is positively associated with the past history of value-destroying M\&As for firms with 
positive free cash flow. In contrast, if a firm has negative free cash flow, such a relation is not to be expected, as the likelihood of an acquisition is much lower. Thus, my third hypothesis is stated as follows:

H3: Information uncertainty, proxied by analyst forecast dispersion, is positively associated with the incidence of value-destroying M\&As when a firm has positive free cash flow.

Firms' past M\&A performance should affect current prices if firms are expected to conduct M\&A in the future. $\mathrm{H} 1$ and $\mathrm{H} 2$ test this idea by using firms' current free cash flow as a proxy for the likelihood of future acquisitions. In the next hypothesis, I examine whether past history affects share prices when the likelihood has materialized. Specifically, I examine whether investors' response to an acquisition announcement is a function of firms' M\&A history. I predict that the stock price reaction to an acquisition announcement will depend on the acquirers' M\&A history, when such an announcement is a significant surprise to investors. If an acquisition is expected and information about the anticipated performance implied by the past has already been impounded in firm value, the short-window return around the announcement should not be systematically related to the over-investment history. To the extent investors assess higher (lower) likelihood of future acquisitions for firms with positive (negative) free cash flow, I therefore expect a negative relation between the stock response to acquisition announcements and the history of value-destroying acquisitions for firms 
with negative free cash flow, but not for firms with positive free cash flow. This prediction is stated in its alternative form as below:

H4: The short-term announcement window return is negatively associated with a firm's incidence of value-destroying M\&As when a firm has negative free cash flow. 


\section{Data and Sample Selection}

\subsection{Sample}

I obtain mergers and acquisitions data from the SDC (Securities Data Company) Platinum database from 1979 to 2007. Similar to Edmans et al. (2012), I remove bids classified as acquisitions of partial stakes, minority squeeze-outs, buybacks, recapitalizations, and exchange offers. Since my main research question requires stock price and return data on acquirers, I examine only U.S. domestic public acquirers. To calculate the past history of mergers and acquisitions, I consider completed transactions and require that the acquirer own less than $50 \%$ of the target's shares prior to the acquisition announcement and more than $50 \%$ of the target's shares after acquisition completion. As my main hypothesis pertains to cash investments, I calculate a firm's past M\&A history based on historical M\&As that are at least partially cash financed, i.e., cash payment accounts for at least $1 \%$ of the transaction value. ${ }^{1}$ Lastly, I remove all small transactions with deal value less than 1 million and all acquiring firms in the financial (SIC code 6000-6999) and utility (SIC code 4000-4999) industries. The final SDC sample consists of 3,870 acquisition deals.

I merge the SDC sample with stock return data from CRSP and accounting data from Compustat. For each firm-year observation with available free cash flow measure

\footnotetext{
${ }^{1}$ Consistent with Bouwman et al. (2009), around 40\% of the deals are financed completely through stocks in my sample. I obtain very similar results if I alternatively require cash payment to be at least $5 \%, 10 \%$ or $20 \%$. Untabulated results show, however, that firm value is not systematically associated with the past M\&A history if I conduct the analysis using completely stock-financed deals. This is consistent with the agency theory explanation of over-investment in M\&A that managers tend to waste cash when they have positive free cash flow.
} 
(FCF, defined in Section 3.2), I calculate a firm's M\&A history over a ten-year rolling window. In addition, to separate the performance consequence on firm values due to M\&A themselves from the valuation effect due to anticipation about future investments, I examine the market valuations of acquiring firms beginning three years after their most recent acquisitions. To be included in the final sample, a firm-year observation must be at least three years past the most recent M\&A completion date to ensure that the performance consequences from past M\&As have been fully realized. ${ }^{2}$ Therefore, the merged sample starts from 1989 and contains 6,290 firm-year observations with 1,451 unique firms. Among these observations, I further exclude firm-years when an acquisition is announced before the fiscal year ends. To ensure that results are not driven by investors' pricing of a concurrent acquisition announcement, as my main hypotheses (H1 to $\mathrm{H} 3)$ are about investors' expectation and pricing of possible upcoming acquisitions. Together, these requirements result in a final sample of 6,218 firm-year observations for the main tests. The sample used to test $\mathrm{H} 4$ is smaller as this hypothesis requires a sample of firm-year observations that are actually associated with an acquisition announcement. The exact timeline is described in Figure 1.

\footnotetext{
2 This design choice works against finding the hypothesized results. Serial acquirers that announce M\&As frequently, where the anticipated firm value discount is likely to be higher, are less likely to be included in the sample.
} 


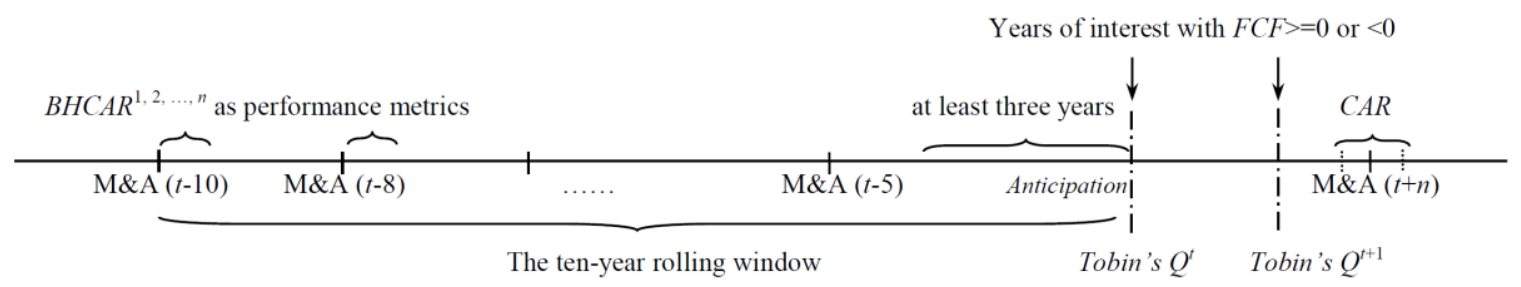

Figure 1: The Timeline

\subsection{Main variable construction and summary statistics}

For each firm-year observation, I calculate that firm's past M\&A performance over a rolling ten-year window. Specifically, to assess whether an M\&A is valueenhancing or value-destroying, I calculate one-year buy-and-hold cumulative abnormal returns $(B H C A R)$ starting from the completion dates of acquisitions. ${ }^{3}$ Following Rau and Vermaelen (1998), I calculate abnormal returns as buy-and-hold returns adjusted by the Fama-French $(1992,1993) 5^{*} 5$ size and book-to-market benchmark portfolios. If the interval between two neighboring M\&As is less than a year, I collect returns since the last M\&A's completion date to 14 days before the next M\&A in calculating BHCAR. I classify an acquisition as value-enhancing (value-destroying) if its one-year post-merger BHCAR is positive (negative). ${ }^{4}$ I then calculate the main independent variable Incidence as the weighted average negative performance incidence. Specifically, Incidence is defined as the ratio of the number of value-destroying M\&As to the total number of M\&As over the ten-year rolling window. To capture the recency effect, I weight each M\&A by ten minus distance in time as the weight, where the distance in time is the

\footnotetext{
${ }^{3}$ Bouwman et al. (2009) show that the post-acquisition long-run market return is more appropriate than the shortwindow announcement return to evaluate acquisition performance. In untabulated tests, I alternatively accumulate returns from the announcement dates of acquisitions. Results and inference are similar to the reported in all aspects.

${ }^{4}$ Consistent with prior research, the mean and median of one-year BHCAR are -0.015 and -0.056 , statistically significant from zero at $10 \%$ and $1 \%$ level, respectively.
} 
number of years between the M\&A and the year of interest in my main test (i.e., the year where I examine the firm's valuation). ${ }^{5}$ This weighting scheme assigns a smaller weight to less recent acquisitions. For instance, if a firm engaged in two acquisitions in year $t-6$ and year $t-4$, respectively, the one in year $t-6$ would receive a weight of 0.4 whereas the other in year $t-4$ would receive a weight of 0.6 . Since I use a ten-year rolling window, Incidence is firm-specific, time-varying, and bounded between 0 and 1. A higher Incidence (more toward to 1 ) indicates a worse past history.

Following Richardson (2006), I calculate free cash flow (FCF) as cash flow beyond what is necessary to maintain assets in place (including servicing existing debt obligations) and finance expected new investments. Specifically, I adopt the method in Richardson (2006) and calculate FCF as follows:

$$
F C F_{i, t}=C F_{A I P, i, t}-I_{\text {new }, i, t}^{*}=C F O_{i, t}-D A_{i, t}+R D_{i, t}-I_{\text {newo }, i, t}^{*}
$$

where $C F O_{i}, t, D A_{i}, t$, and $R D_{i, t}$ are cash flow from operations, depreciation and amortization expense, $R \& D$ expense for firm $i$ in year $t$ scaled by total assets, respectively. Inew, ${ }^{*} i, t$ is the expected new capital expenditure, estimated as the predicted value from estimating equation [2] below:

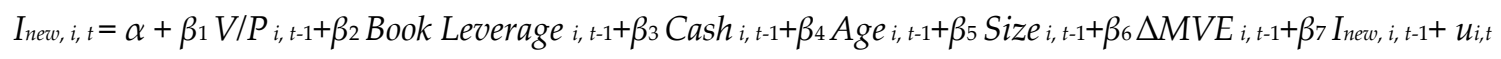

\footnotetext{
${ }^{5} \mathrm{I}$ also calculate Incidence as a simple average of negative performance incidence, a deal-size weighted average of negative performance incidence, or a simple (weighted) average of BHCAR. Results are similar to those reported in all aspects.
} 
Equation [2] is estimated with industry and year fixed effects over the entire sample with available data in Compustat. $I_{n e w}, i, t$ in equation [2] is new capital investment, defined as the difference between total capital investment and investment to maintain assets in place for firm $i$ in year $t$, deflated by total assets. Total capital investment is calculated as R\&D expenditure plus capital expenditure plus acquisition expenditure less cash receipts from PPE disposal. Investment to maintain assets in place is proxied by depreciation and amortization expense. All variables in equation [2] are predictors of new capital expenditure and are defined as in Richardson (2006). Specifically, V/P is a measure of growth opportunities and is calculated as the ratio of the Ohlson model (1995) firm value (VAIP) to the market value of equity. ${ }^{6}$ Book Leverage is measured as the sum of current debt and long-term debt, deflated by the sum of book value of total debt and book value of equity. Cash is measured as cash and short-term investments, deflated by total assets. Age is the log of the number of years the firm has been listed on CRSP. Size is the log of total assets. $\triangle M V E$ is the change in market value of the firm from the prior year. $I_{\text {new, } i, t-1}$ is the new capital investment in year $t-1$, deflated by total assets. I calculate FCF as in [1] for each firm-year observation in my final sample and use it as a partitioning variable in the main tests. ${ }^{7}$ I hypothesize that investors perceive firms with positive FCF as likely acquirers because these firms have internally generated cash to

\footnotetext{
${ }^{6}$ As in Richardson (2006), VAIP is estimated as $(1-\alpha r) B V+\alpha(1+r) X-\alpha \cdot r \cdot d$, where $\alpha=\frac{\omega}{1+r-\omega} \cdot \omega$ is the abnormal earnings persistence parameter and takes a value of $0.62 . d$ is annual dividends. $X$ is operating income after depreciation. $r$ is the discount rate and takes a value of $12 \%$.

${ }^{7}$ Estimation results are very similar to that in Richardson (2006) and are available upon requests.
} 
make acquisitions. Likewise, I hypothesize that investors perceive firms with negative FCF as unlikely acquirers.

Table 1, Panel A presents the descriptive statistics of M\&A deals. The mean values of M\&A transaction value and the cash portion of the transaction value in my sample are $\$ 480$ million and $\$ 326$ million, respectively. On average, the size of the deal (the cash payment portion) represents $28 \%$ (20\%) of an acquirer firm's pre-acquisition market capitalization. This is consistent with the notion that acquisitions are a significant investment in terms of both transaction size and cash expenditure.

Table 1: Descriptive Statistics

Panel A: Deal Descriptive Statistics

\begin{tabular}{lcccccc}
\hline \hline Variable & $\mathrm{N}$ & Mean & P25 & Median & P75 & Std Dev \\
\hline Deal & 3,870 & 480.15 & 17.50 & 64.00 & 250.00 & $2,169.90$ \\
Cash Deal & 3,870 & 325.52 & 10.00 & 44.45 & 185.00 & $1,280.13$ \\
MVE (Acquirer) & 3,870 & $7,763.20$ & 173.00 & 736.78 & $3,104.20$ & $27,123.11$ \\
Deal/MVE & 3,870 & 0.28 & 0.03 & 0.10 & 0.29 & 0.64 \\
Cash Deal/MVE & 3,870 & 0.20 & 0.02 & 0.07 & 0.19 & 0.54 \\
\hline \hline
\end{tabular}

This panel reports the descriptive statistics for the M\&A deals studied in this paper. Deal is total transaction value of the M\&A deal (in millions). Cash deal is the cash payment portion of the deal (in millions). MVE is the acquirer's pre-acquisition market value of equity (in millions). Deal/MVE is the relative deal size scaled by acquirer's MVE. Cash deal/MVE is the relative cash payment portion scaled by acquirer's MVE. 
Panel B: Sample Descriptive Statistics

\begin{tabular}{|c|c|c|c|c|c|c|c|c|c|c|c|c|c|c|}
\hline \multirow[b]{2}{*}{ Variable } & \multirow[b]{2}{*}{$\mathrm{N}$} & \multicolumn{5}{|c|}{ Full Sample } & \multicolumn{4}{|c|}{$\mathrm{FCF}>=0($ Positive $\mathrm{FCF}=1)$} & \multicolumn{4}{|c|}{ FCF $<0($ Positive FCF $=0)$} \\
\hline & & Mean & P25 & Median & P75 & Std Dev & $\mathrm{N}$ & Mean & Median & Std Dev & $\mathrm{N}$ & Mean & Median & Std Dev \\
\hline $\mathrm{Q}$ & 6,218 & 1.70 & 1.10 & 1.39 & 1.90 & 1.03 & 3,835 & 1.81 & 1.48 & 1.08 & 2,365 & 1.52 & 1.27 & 0.91 \\
\hline FCF & 6,218 & 0.01 & -0.03 & 0.02 & 0.06 & 0.09 & 3,835 & 0.06 & 0.05 & 0.05 & 2,365 & -0.07 & -0.05 & 0.08 \\
\hline Incidence & 6,218 & 0.56 & 0.00 & 1.00 & 1.00 & 0.47 & 3,835 & 0.55 & 0.87 & 0.47 & 2,365 & 0.57 & 1.00 & 0.47 \\
\hline Size & 6,218 & 6.75 & 5.35 & 6.76 & 8.14 & 1.93 & 3,835 & 7.04 & 7.06 & 1.90 & 2,365 & 6.29 & 6.27 & 1.89 \\
\hline Sales & 6,218 & 6.71 & 5.36 & 6.69 & 8.09 & 1.92 & 3,835 & 7.06 & 7.09 & 1.84 & 2,365 & 6.14 & 6.10 & 1.92 \\
\hline MTB & 6,218 & 2.82 & 1.27 & 1.94 & 3.05 & 4.28 & 3,835 & 2.96 & 2.14 & 3.65 & 2,365 & 2.58 & 1.67 & 5.15 \\
\hline $\mathrm{RD}$ & 6,218 & 0.44 & 0.00 & 0.01 & 0.24 & 1.11 & 3,835 & 0.41 & 0.03 & 1.03 & 2,365 & 0.49 & 0.00 & 1.23 \\
\hline Adv & 6,218 & 0.09 & 0.00 & 0.00 & 0.04 & 0.25 & 3,835 & 0.09 & 0.00 & 0.25 & 2,365 & 0.08 & 0.00 & 0.24 \\
\hline Capex & 6,218 & 0.23 & 0.13 & 0.20 & 0.30 & 0.15 & 3,835 & 0.23 & 0.19 & 0.14 & 2,365 & 0.25 & 0.20 & 0.17 \\
\hline Margin & 6,218 & 0.12 & 0.06 & 0.12 & 0.19 & 0.17 & 3,835 & 0.16 & 0.14 & 0.12 & 2,365 & 0.06 & 0.09 & 0.23 \\
\hline Leverage & 6,218 & 0.24 & 0.06 & 0.19 & 0.37 & 0.22 & 3,835 & 0.22 & 0.16 & 0.21 & 2,365 & 0.28 & 0.24 & 0.24 \\
\hline TA & 6,218 & 4,160 & 210 & 863 & 3,432 & 8,721 & 3,835 & 5,098 & 1,160 & 9,904 & 2,365 & 2,631 & 529 & 6,036 \\
\hline MVE & 6,218 & 4,599 & 162 & 754 & 3,038 & 11,783 & 3,835 & 6,120 & 1,192 & 13,898 & 2,365 & 2,123 & 380 & 6,361 \\
\hline K & 6,218 & 0.37 & 0.10 & 0.19 & 0.37 & 0.57 & 3,835 & 0.32 & 0.18 & 0.44 & 2,365 & 0.45 & 0.19 & 0.73 \\
\hline$\Delta$ Cash & 6,033 & 0.01 & -0.02 & 0.00 & 0.04 & 0.09 & 3,758 & 0.03 & 0.01 & 0.08 & 2,275 & -0.01 & 0.00 & 0.11 \\
\hline$\Delta \mathrm{E}$ & 6,033 & 0.02 & -0.03 & 0.01 & 0.04 & 0.17 & 3,758 & 0.03 & 0.01 & 0.15 & 2,275 & 0.00 & 0.00 & 0.20 \\
\hline$\triangle \mathrm{NA}$ & 6,033 & 0.03 & -0.06 & 0.02 & 0.11 & 0.32 & 3,758 & 0.01 & 0.02 & 0.28 & 2,275 & 0.06 & 0.04 & 0.37 \\
\hline$\Delta R D$ & 6,033 & 0.00 & 0.00 & 0.00 & 0.00 & 0.02 & 3,758 & 0.00 & 0.00 & 0.01 & 2,275 & 0.00 & 0.00 & 0.02 \\
\hline$\Delta$ Interest & 6,033 & 0.00 & 0.00 & 0.00 & 0.00 & 0.02 & 3,758 & 0.00 & 0.00 & 0.02 & 2,275 & 0.00 & 0.00 & 0.02 \\
\hline$\Delta$ Div & 6,033 & 0.00 & 0.00 & 0.00 & 0.00 & 0.03 & 3,758 & 0.00 & 0.00 & 0.03 & 2,275 & 0.00 & 0.00 & 0.03 \\
\hline Casht-1 & 6,033 & 0.14 & 0.03 & 0.07 & 0.17 & 0.17 & 3,758 & 0.12 & 0.07 & 0.14 & 2,275 & 0.17 & 0.09 & 0.20 \\
\hline NF & 6,033 & 0.00 & -0.01 & 0.00 & 0.01 & 0.07 & 3,758 & 0.00 & 0.00 & 0.05 & 2,275 & 0.02 & 0.00 & 0.08 \\
\hline
\end{tabular}

This panel reports the descriptive statistics for firm characteristics. Tobin's $Q$ is the sum of market value of equity, liquidation value of preferred equity and book value of total liabilities scaled by total assets. FCF is measured as in Richardson (2006) in equation [1]. Incidence is weighted average negative performance incidence defined in the main text. Size is logged total assets. Sales is logged annual sales number. Marketto-book is the ratio of market value of equity to book value of equity. $\mathrm{RD}$ is annual research and development expenditure scaled by property, plant, and equipment (PPE). Adv is annual advertising expense scaled by PPE. Capex is annual capital expenditure scaled PPE. Margin is the ratio of operating income before depreciation to sales. Leverage is the market leverage defined as total debt over the sum of total debt and the market value of equity. TA is total assets. MVE is market value of equity. $\mathrm{K}$ is property, plant, and equipment scaled by sales. $\Delta$ Cash is the change in cash scaled by lagged market value of equity. Casht-1 is cash balance from last year. $\triangle$ EBIT is the change in earnings before extraordinary items plus interest, deferred tax credits, and investment tax credits. $\Delta$ Net Asset is the change in net assets where net assets are defined as total assets minus cash holdings scaled by lagged market value of equity. $\Delta$ Interest is the change in interest expense scaled by lagged market value of equity. $\Delta$ Dividend is the change in common dividends paid scaled by lagged market value of equity. Net Financing is the total equity issuance minus repurchases plus debt issuance minus debt redemption scaled by lagged market value of equity. $\triangle R D$ is the change in R\&D expenditures scaled by lagged market value of equity. 
Table 1, Panel B presents the descriptive statistics for variables used in the main tests. The primary dependent variable is Tobin's $Q$, calculated as the sum of market value of equity, liquidation value of preferred equity, and book value of total liabilities, scaled by the book value of total assets. Originally proposed by Tobin (1969) and formalized in Hayashi (1982), Tobin's $Q$ measures investors' valuation of a firm's investment opportunities. As shown in Table 1, Panel B, the sample mean of Tobin's $Q$ is 1.70. The subsample means of Tobin's $Q$ are 1.81 and 1.52 for the positive FCF sample and negative FCF sample, respectively. The difference is statistically significant $(t$-statistic $=10.63$, untabulated), consistent with idea that firms generating positive free cash flow are valued higher. The overall sample mean of Incidence is 0.56 . While the means of Incidence for the two subsamples ( 0.55 and 0.57 for the positive and negative FCF subsample) are statistically different from each other at the $10 \%$ level (t-statistic 1.78 , untabulated), the economic magnitude of the difference does not appear to be significant.

Table 1, Panel B also provides summary statistics for other test variables. Specifically, FCF is defined in equation [1]; Size is logged total assets; MTB is the ratio of market value of equity to book value of equity; Sales is logged annual sales; $R D$ is annual research and development expenditure, scaled by property, plant, and equipment (PPE); $A d v$ is annual advertising expense scaled by PPE; Capex is annual capital expenditure scaled by PPE; and $K$ is property, plant, and equipment (PPE), scaled by sales. As I conduct most analyses separately for positive FCF and negative FCF samples, I also report descriptive statistics in these two subsamples. 
Table 2 presents the sample correlations for variables used in the main firm value test. Pearson correlations for the positive and negative FCF samples are presented in the upper and lower corner, respectively, with $p$-values presented underneath the correlations. This table provides some preliminary evidence supporting H1. Incidence is negatively correlated with Tobin's $Q$ in the Positive FCF sample but is insignificantly correlated with Tobin's $Q$ in the negative FCF sample. These results are consistent with the hypothesis that firm values are negatively related to the history of value-destroying M\&As for firms that are more likely to engage in future M\&As.

Table 2: Correlation Table

\begin{tabular}{|c|c|c|c|c|c|c|c|c|c|c|c|c|}
\hline & Q & Incidence & Sales & $\mathrm{RD}$ & Adv & Capex & Margin & Leverage & $\mathrm{K}$ & $\mathrm{BM}$ & $\Delta$ Cash & $\Delta$ Cash $^{\text {Unexpected }}$ \\
\hline Q & & $\begin{array}{c}-0.14 \\
(0.00)\end{array}$ & $\begin{array}{c}0.02 \\
(0.31)\end{array}$ & $\begin{array}{c}0.19 \\
(0.00)\end{array}$ & $\begin{array}{c}0.03 \\
(0.08)\end{array}$ & $\begin{array}{c}0.25 \\
(0.00)\end{array}$ & $\begin{array}{c}0.26 \\
(0.00)\end{array}$ & $\begin{array}{l}-0.44 \\
(0.00)\end{array}$ & $\begin{array}{l}-0.08 \\
(0.00)\end{array}$ & $\begin{array}{l}-0.46 \\
(0.00)\end{array}$ & $\begin{array}{c}0.11 \\
(0.00)\end{array}$ & $\begin{array}{l}-0.01 \\
(0.48)\end{array}$ \\
\hline Incidence & $\begin{array}{c}0.01 \\
(0.53)\end{array}$ & & $\begin{array}{l}-0.09 \\
(0.00)\end{array}$ & $\begin{array}{c}0.04 \\
(0.01)\end{array}$ & $\begin{array}{c}0.00 \\
(0.96)\end{array}$ & $\begin{array}{c}0.01 \\
(0.35)\end{array}$ & $\begin{array}{l}-0.13 \\
(0.00)\end{array}$ & $\begin{array}{c}0.07 \\
(0.00)\end{array}$ & $\begin{array}{l}-0.06 \\
(0.00)\end{array}$ & $\begin{array}{c}0.07 \\
(0.00)\end{array}$ & $\begin{array}{l}-0.04 \\
(0.09)\end{array}$ & $\begin{array}{c}0.03 \\
(0.14)\end{array}$ \\
\hline Sales & $\begin{array}{l}-0.19 \\
(0.00)\end{array}$ & $\begin{array}{l}-0.15 \\
(0.00)\end{array}$ & & $\begin{array}{c}-0.29 \\
(0.00)\end{array}$ & $\begin{array}{l}-0.04 \\
(0.03)\end{array}$ & $\begin{array}{l}-0.22 \\
(0.00)\end{array}$ & $\begin{array}{c}0.15 \\
(0.00)\end{array}$ & $\begin{array}{c}0.15 \\
(0.00)\end{array}$ & $\begin{array}{c}0.09 \\
(0.00)\end{array}$ & $\begin{array}{l}-0.02 \\
(0.36)\end{array}$ & $\begin{array}{c}0.03 \\
(0.16)\end{array}$ & $\begin{array}{l}-0.18 \\
(0.00)\end{array}$ \\
\hline RD & $\begin{array}{c}0.06 \\
(0.00)\end{array}$ & $\begin{array}{c}0.03 \\
(0.20)\end{array}$ & $\begin{array}{l}-0.13 \\
(0.00)\end{array}$ & & $\begin{array}{c}0.09 \\
(0.00)\end{array}$ & $\begin{array}{c}0.37 \\
(0.00)\end{array}$ & $\begin{array}{l}-0.15 \\
(0.00)\end{array}$ & $\begin{array}{l}-0.25 \\
(0.00)\end{array}$ & $\begin{array}{l}-0.17 \\
(0.00)\end{array}$ & $\begin{array}{l}-0.12 \\
(0.00)\end{array}$ & $\begin{array}{l}-0.03 \\
(0.23)\end{array}$ & $\begin{array}{c}0.23 \\
(0.00)\end{array}$ \\
\hline Adv & $\begin{array}{c}0.02 \\
(0.31)\end{array}$ & $\begin{array}{c}0.02 \\
(0.36)\end{array}$ & $\begin{array}{l}-0.05 \\
(0.03)\end{array}$ & $\begin{array}{c}0.03 \\
(0.00)\end{array}$ & & $\begin{array}{c}0.14 \\
(0.00)\end{array}$ & $\begin{array}{l}-0.03 \\
(0.06)\end{array}$ & $\begin{array}{l}-0.01 \\
(0.64)\end{array}$ & $\begin{array}{l}-0.06 \\
(0.00)\end{array}$ & $\begin{array}{l}-0.01 \\
(0.61)\end{array}$ & $\begin{array}{c}0.01 \\
(0.62)\end{array}$ & $\begin{array}{c}0.07 \\
(0.00)\end{array}$ \\
\hline Capex & $\begin{array}{c}0.17 \\
(0.00)\end{array}$ & $\begin{array}{c}0.05 \\
(0.01)\end{array}$ & $\begin{array}{l}-0.22 \\
(0.00)\end{array}$ & $\begin{array}{c}0.10 \\
(0.00)\end{array}$ & $\begin{array}{c}0.08 \\
(0.00)\end{array}$ & & $\begin{array}{l}-0.02 \\
(0.19)\end{array}$ & $\begin{array}{l}-0.32 \\
(0.00)\end{array}$ & $\begin{array}{l}-0.22 \\
(0.00)\end{array}$ & $\begin{array}{l}-0.16 \\
(0.00)\end{array}$ & $\begin{array}{l}-0.02 \\
(0.30)\end{array}$ & $\begin{array}{c}0.10 \\
(0.00)\end{array}$ \\
\hline Margin & $\begin{array}{l}-0.25 \\
(0.00)\end{array}$ & $\begin{array}{c}0.02 \\
(0.33)\end{array}$ & $\begin{array}{c}0.22 \\
(0.00)\end{array}$ & $\begin{array}{l}-0.08 \\
(0.00)\end{array}$ & $\begin{array}{c}0.00 \\
(0.88)\end{array}$ & $\begin{array}{l}-0.04 \\
(0.04)\end{array}$ & & $\begin{array}{c}-0.10 \\
(0.00)\end{array}$ & $\begin{array}{c}0.47 \\
(0.00)\end{array}$ & $\begin{array}{c}0.01 \\
(0.48)\end{array}$ & $\begin{array}{c}0.06 \\
(0.00)\end{array}$ & $\begin{array}{l}-0.15 \\
(0.00)\end{array}$ \\
\hline Leverage & $\begin{array}{l}-0.22 \\
(0.00)\end{array}$ & $\begin{array}{c}0.07 \\
(0.00)\end{array}$ & $\begin{array}{l}0.28 \\
0.00)\end{array}$ & $\begin{array}{l}-0.09 \\
(0.00)\end{array}$ & $\begin{array}{l}-0.06 \\
(0.00)\end{array}$ & $\begin{array}{l}-0.28 \\
(0.00)\end{array}$ & $\begin{array}{c}0.07 \\
(0.00)\end{array}$ & & $\begin{array}{c}0.21 \\
(0.00)\end{array}$ & $\begin{array}{c}0.44 \\
(0.00)\end{array}$ & $\begin{array}{l}-0.00 \\
(0.84)\end{array}$ & $\begin{array}{l}-0.15 \\
(0.00)\end{array}$ \\
\hline K & $\begin{array}{c}0.01 \\
(0.60)\end{array}$ & $\begin{array}{l}-0.06 \\
(0.01)\end{array}$ & $\begin{array}{c}-0.13 \\
(0.00)\end{array}$ & $\begin{array}{c}-0.03 \\
(0.19)\end{array}$ & $\begin{array}{l}-0.06 \\
(0.00)\end{array}$ & $\begin{array}{l}-0.09 \\
(0.00)\end{array}$ & $\begin{array}{c}-0.41 \\
(0.00)\end{array}$ & $\begin{array}{c}0.08 \\
(0.00)\end{array}$ & & $\begin{array}{l}-0.01 \\
(0.81)\end{array}$ & $\begin{array}{c}0.04 \\
(0.07)\end{array}$ & $\begin{array}{c}0.01 \\
(0.62)\end{array}$ \\
\hline $\mathrm{BM}$ & $\begin{array}{c}-0.54 \\
(0.00)\end{array}$ & $\begin{array}{c}0.10 \\
(0.00)\end{array}$ & $\begin{array}{c}-0.20 \\
(0.00)\end{array}$ & $\begin{array}{l}-0.06 \\
(0.00)\end{array}$ & $\begin{array}{l}-0.00 \\
(0.90)\end{array}$ & $\begin{array}{l}-0.14 \\
(0.00)\end{array}$ & $\begin{array}{l}-0.29 \\
(0.00)\end{array}$ & $\begin{array}{c}0.45 \\
(0.00)\end{array}$ & $\begin{array}{c}0.01 \\
(0.46)\end{array}$ & & $\begin{array}{l}-0.11 \\
(0.00)\end{array}$ & $\begin{array}{l}-0.01 \\
(0.61)\end{array}$ \\
\hline$\Delta$ Cash & $\begin{array}{l}-0.02 \\
(0.27)\end{array}$ & $\begin{array}{c}0.03 \\
(0.10)\end{array}$ & $\begin{array}{l}-0.08 \\
(0.00)\end{array}$ & $\begin{array}{c}0.06 \\
(0.00)\end{array}$ & $\begin{array}{c}0.05 \\
(0.00)\end{array}$ & $\begin{array}{l}-0.01 \\
(0.61)\end{array}$ & $\begin{array}{l}-0.06 \\
(0.00)\end{array}$ & $\begin{array}{c}0.01 \\
(0.49)\end{array}$ & $\begin{array}{l}-0.06 \\
(0.00)\end{array}$ & $\begin{array}{c}0.05 \\
(0.00)\end{array}$ & & $\begin{array}{c}0.25 \\
(0.00)\end{array}$ \\
\hline$\Delta$ Cash $^{\text {Unexpected }}$ & $\begin{array}{l}-0.09 \\
(0.00)\end{array}$ & $\begin{array}{c}0.08 \\
(0.00)\end{array}$ & $\begin{array}{l}-0.13 \\
(0.00)\end{array}$ & $\begin{array}{c}0.24 \\
(0.00)\end{array}$ & $\begin{array}{c}0.11 \\
(0.00)\end{array}$ & $\begin{array}{c}0.07 \\
(0.00)\end{array}$ & $\begin{array}{l}-0.15 \\
(0.00)\end{array}$ & $\begin{array}{c}-0.01 \\
(0.41)\end{array}$ & $\begin{array}{c}-0.10 \\
(0.00)\end{array}$ & $\begin{array}{c}0.09 \\
(0.00)\end{array}$ & $\begin{array}{c}0.57 \\
(0.00)\end{array}$ & \\
\hline
\end{tabular}

This table reports the sample correlation for variables used in the main firm value test. Pearson correlations are presented in the upper corner for the positive FCF sample and in the lower corner for the negative FCF sample, respectively. P-values are presented underneath the correlations. Tobin's $Q$ is the sum of market value of equity, liquidation value of preferred equity and book value of total liabilities scaled by total assets. 
Sales is logged annual sales number. RD is annual research and development expenditure scaled by PPE.

$\mathrm{Adv}$ is annual advertising expense scaled by PPE. Capex is annual capital expenditure scaled by PPE. Margin is the ratio of operating income before depreciation to sales. Leverage is the market leverage defined as total debt over the sum of total debt and the market value of equity. $\mathrm{K}$ is property, plant, and equipment scaled by sales. $B M$ is the book-to-market ratio. $\Delta$ Cash is the change in cash scaled by lagged market value of equity. $\Delta$ Cash $^{\text {Excess }}$ is the change in unexpected cash (defined in Section 4.3). 


\section{Main empirical analysis}

\subsection{Validating the use of FCF as a proxy for future M\&A}

An important assumption in my empirical analysis is that firms with positive free cash flow are more likely to make future acquisitions than firms with negative free cash flow. This assumption is motivated theoretically by Jensen's free cash flow hypothesis in that firms with free cash flow are more likely to make empire-building investments. While this assumption has found empirical support from prior literature (e.g., Lang et al. (1991) among others), I provide empirical evidence for its validity for my sample of firms. Specifically, I estimate a Logit model that predicts acquisitions with FCF (Positive FCF) and other firm characteristics. The Logit model is similar to that in Harford (1999) and Song and Walkling (2000):

\section{Acquisition ${ }_{i, t}$}

$=\alpha+\beta_{1}$ FCF $_{i, t}$ (or Positive $\left.C F_{i, t}\right)+\beta_{2}$ Size $_{i, t}+\beta_{3}$ Growth $_{i, t}+\beta_{4} M T B_{i, t}+\beta_{5} P E_{i, t}+\beta_{6} L_{e v} i_{i, t}+\beta_{7} N W C A P_{i, t}+\mathcal{u}_{i, t}$

where the dependent variable Acquisition takes a value of one if a firm-year observation is associated with a merger and acquisition announcement in the $[-183,183]$ window around the annual fiscal period end date. I select this window to capture the idea that managers make M\&A decisions when the realization of operations in a year is known or close to known to managers. Size is logged total assets. Growth, MTB, PE, Lev, and NWCAP are sales growth, market-to-book ratio, price-to-earnings ratio, market leverage ratio (defined as total debt over the sum of total debt and market value of equity), and non-cash working capital scaled by total assets, all averaged over the past four years, 
respectively. FCF is defined in equation [1]. Positive FCF is defined the same as above. I include year fixed effects in all panel data regressions throughout this paper. In addition, to avoid both cross-sectional and time-series dependence, all standard errors are clustered both by firm and by year (Petersen (2009)). To the extent that firms with positive free cash flow are more likely to attempt acquisitions, I expect a positive coefficient estimate for FCF and Positive FCF.

Table 3: Predicting Acquisitions

\begin{tabular}{lccc}
\hline \hline & Predicted signs & $(1)$ & $(2)$ \\
\hline FCF & + & $2.139^{* * *}$ & \\
& & $(2.71)$ & \\
Positive FCF & + & & $0.288^{* *}$ \\
& & & $(2.57)$ \\
Size & + & $0.287^{* * *}$ & $0.290^{* * *}$ \\
& & $(7.78)$ & $(7.98)$ \\
Growth & + & $1.357^{* * *}$ & $1.291^{* * *}$ \\
& & $(4.87)$ & $(4.46)$ \\
Lev & - & $-2.314^{* * *}$ & $-2.374^{* * *}$ \\
& & $(-4.97)$ & $(-4.97)$ \\
MTB & & -0.021 & -0.012 \\
& & $(-0.59)$ & $(-0.34)$ \\
PE & & -0.0008 & -0.0008 \\
& & $(-0.36)$ & $(-0.35)$ \\
NWCAP & & -0.359 & -0.291 \\
& & $(-0.69)$ & $(-0.56)$ \\
Intercept & & Yes & Yes \\
N & & 6,290 & 6,290 \\
Pseudo R-squared & & 0.082 & 0.081 \\
\hline \hline
\end{tabular}

This table reports results from a Logit regression of acquisition likelihood on firm characteristics. The dependent variable Acquisition takes one if a firm-year observation is associated with merger and acquisition announcement and zero otherwise. FCF is measured as in Richardson (2006) in equation [1]. Positive FCF is a dummy variable and takes one if the free cash flow measured as in Richardson (2006) is positive and zero otherwise. Size is logged total assets. Sales Growth is the average sales growth rate over the past four years. Market-to-book is the average market-to-book ratio over the past four years. Price-toearnings is the average price-to-earnings ratio over the past four years. Leverage is the average market 
leverage ratio over the past four years where leverage ratio is calculated as total debt over the sum of total debt and the market value of equity. Non-cash working capital is the average working capital scaled by total assets over the past four years. All standard errors are two-way clustered by both firm and year. Z-statistics are presented underneath the coefficient estimates and ${ }^{* *}, * *$, and ${ }^{*}$ indicate that estimates are significantly different from zero at $1 \%, 5 \%$, and $10 \%$ level, respectively.

Table 3 presents the estimation results. In Column (1), the coefficient estimate for FCF $(\beta=2.139, z$-statistic $=2.71)$ is statistically significant from zero at the $1 \%$ level. In Column (2), the coefficient estimate for Positive FCF $(\beta=0.288$, $z$-statistic $=2.57)$ is positively and statistically significantly associated with the likelihood of attempting an acquisition, consistent with firms with positive free cash flow being more likely to be acquirers. Coefficients on other firm characteristics are consistent with prior research. I conclude from this table that firms with positive free cash flow are more likely to engage in acquisitions. Viewed together with findings in Richardson (2006), firms with positive free cash flow have both the tendency and ability to invest in future acquisitions. Therefore, it is appropriate to use free cash flow (i.e., the dummy variable Positive FCF) as my main partitioning variable to group firms into likely acquirers and unlikely acquirers. $^{1}$

\subsection{Evidence for the anticipation discount}

To examine whether investors place a discount on firms with anticipated valuedestroying M\&As, I apply the specification proposed by Himmelberg et al. (1999) and used by several recent studies (e.g., Habib and Ljungqvist (2005), Edmans et al. (2012)):

\footnotetext{
${ }^{1}$ Results are similar if I use the predicted probability from equation [3] to partition firms into likely acquirers and unlikely acquirers.
} 
$Q_{i, t}=\alpha+\beta_{1}$ Sales $_{i, t}+\beta_{2}$ Sales $^{2}, t+\beta_{3} R D_{i, t}+\beta_{4} A d v_{i, t}+\beta_{5}$ Capex $_{i, t}+\beta_{6}$ Margini $_{i, t}+\beta_{7}$ Leverage $_{i, t}+\beta_{8} K_{i, t}+\beta_{9} K^{2}, t+$

$\beta_{10}$ Incidence $i_{i}+u_{i, t}[4]$

where $Q$ is Tobin's $Q$ and other firm characteristics are as defined earlier. ${ }^{2}$ I estimate equation [4] on three samples: positive FCF, negative FCF, and the full sample. The main independent variable in these regressions is Incidence, defined in Section 3.2. H1 predicts a negative coefficient estimate on Incidence in the positive FCF sample but not on the negative FCF sample.

${ }^{2}$ An alternative approach to examine investors' expectations is to use analysts' forecasted price targets. In untabulated robustness checks, I also conduct analysis in a subsample using analysts' forecasted price targets to calculate expected Tobin's $Q$ in the robustness check section. Results and inferences are very similar to those reported in Table 4. 
Table 4: Firm Value Test

Panel A: The Main Test

\begin{tabular}{|c|c|c|c|c|c|c|}
\hline & (1) & (2) & (3) & (4) & $(5)$ & (6) \\
\hline & \multicolumn{3}{|c|}{ Main Sample } & \multicolumn{3}{|c|}{ Matched Pseudo Sample } \\
\hline & FCF $>=0$ & $\mathrm{FCF}<0$ & Full sample & FCF $>=0$ & $\mathrm{FCF}<0$ & Full sample \\
\hline Incidence & $\begin{array}{c}-0.179^{* * *} \\
(-3.42)\end{array}$ & $\begin{array}{c}-0.0131 \\
(-0.28)\end{array}$ & $\begin{array}{c}0.0564 \\
(1.03)\end{array}$ & $\begin{array}{c}-0.0795 \\
(-1.02)\end{array}$ & $\begin{array}{l}-0.107 \\
(-1.42)\end{array}$ & $\begin{array}{c}-0.0668 \\
(-0.87)\end{array}$ \\
\hline Positive FCF & & & $\begin{array}{c}0.297^{* * *} \\
(5.30)\end{array}$ & & & $\begin{array}{c}0.359^{* * * *} \\
(4.80)\end{array}$ \\
\hline Positive FCF* Incidence & & & $\begin{array}{c}-0.290^{* * *} \\
(-3.58)\end{array}$ & & & $\begin{array}{l}-0.130 \\
(-1.26)\end{array}$ \\
\hline Sales & $\begin{array}{l}0.0237 \\
(0.20)\end{array}$ & $\begin{array}{c}-0.378^{* *} \\
(-2.31)\end{array}$ & $\begin{array}{l}-0.220^{*} \\
(-1.78)\end{array}$ & $\begin{array}{c}-0.0143 \\
(-0.12)\end{array}$ & $\begin{array}{c}-0.382^{* * *} \\
(-2.85)\end{array}$ & $\begin{array}{l}-0.198^{*} \\
(-1.87)\end{array}$ \\
\hline Sales $^{2}$ & $\begin{array}{c}0.00128 \\
(0.16)\end{array}$ & $\begin{array}{c}0.0262^{* *} \\
(2.27)\end{array}$ & $\begin{array}{c}0.0169^{* *} \\
(2.01)\end{array}$ & $\begin{array}{c}0.00376 \\
(0.44)\end{array}$ & $\begin{array}{c}0.0281^{* * *} \\
(2.84)\end{array}$ & $\begin{array}{c}0.0170^{* *} \\
(2.21)\end{array}$ \\
\hline RD & $\begin{array}{c}0.0962^{* *} \\
(2.04)\end{array}$ & $\begin{array}{c}0.0214 \\
(0.73)\end{array}$ & $\begin{array}{c}0.0621^{*} \\
(1.79)\end{array}$ & $\begin{array}{c}-0.00430 \\
(-0.12)\end{array}$ & $\begin{array}{c}0.122^{* *} \\
(2.54)\end{array}$ & $\begin{array}{c}0.0623^{*} \\
(1.71)\end{array}$ \\
\hline Adv & $\begin{array}{l}0.0248 \\
(0.21)\end{array}$ & $\begin{array}{c}0.0190 \\
(0.18)\end{array}$ & $\begin{array}{c}-0.00826 \\
(-0.10)\end{array}$ & $\begin{array}{l}0.120 \\
(1.03)\end{array}$ & $\begin{array}{c}-0.213^{* * *} \\
(-2.95)\end{array}$ & $\begin{array}{l}-0.0127 \\
(-0.14)\end{array}$ \\
\hline Capex & $\begin{array}{c}0.783^{* * *} \\
(3.38)\end{array}$ & $\begin{array}{c}0.435^{* *} \\
(2.43)\end{array}$ & $\begin{array}{c}0.753^{* * *} \\
(4.79)\end{array}$ & $\begin{array}{c}1.296^{* * * *} \\
(4.43)\end{array}$ & $\begin{array}{c}0.555^{* *} \\
(2.38)\end{array}$ & $\begin{array}{c}1.045^{* * *} \\
(5.36)\end{array}$ \\
\hline Margin & $\begin{array}{c}3.099^{* * *} \\
(7.90)\end{array}$ & $\begin{array}{l}-0.109 \\
(-0.64)\end{array}$ & $\begin{array}{c}0.617^{* * *} \\
(3.20)\end{array}$ & $\begin{array}{c}1.911^{* * *} \\
(3.25)\end{array}$ & $\begin{array}{c}-0.279^{* *} \\
(-2.32)\end{array}$ & $\begin{array}{c}-0.256^{* *} \\
(-2.10)\end{array}$ \\
\hline Leverage & $\begin{array}{c}-1.930^{* * * *} \\
(-10.42)\end{array}$ & $\begin{array}{c}-1.491^{* * *} \\
(-8.15)\end{array}$ & $\begin{array}{c}-2.001^{* * *} \\
(-10.76)\end{array}$ & $\begin{array}{c}-2.599^{* * *} \\
(-14.05)\end{array}$ & $\begin{array}{c}-1.566^{* * *} \\
(-10.55)\end{array}$ & $\begin{array}{c}-2.262^{* * *} \\
(-14.36)\end{array}$ \\
\hline K & $\begin{array}{l}-0.271^{*} \\
(-1.90)\end{array}$ & $\begin{array}{c}0.387^{* * *} \\
(3.92)\end{array}$ & $\begin{array}{c}0.260^{* * *} \\
(2.67)\end{array}$ & $\begin{array}{l}-0.377^{*} \\
(-1.69)\end{array}$ & $\begin{array}{l}0.159 \\
(1.64)\end{array}$ & $\begin{array}{l}0.0980 \\
(1.42)\end{array}$ \\
\hline $\mathrm{K}^{2}$ & $\begin{array}{c}-0.0559 \\
(-1.44)\end{array}$ & $\begin{array}{c}-0.109^{* * *} \\
(-3.46)\end{array}$ & $\begin{array}{c}-0.0844^{* * *} \\
(-2.78)\end{array}$ & $\begin{array}{c}0.0187 \\
(0.54)\end{array}$ & $\begin{array}{c}-0.0188 \\
(-0.68)\end{array}$ & $\begin{array}{c}-0.00618 \\
(-0.30)\end{array}$ \\
\hline Missing RD & $\begin{array}{l}0.0001 \\
(-1.96)\end{array}$ & $\begin{array}{c}0.0004^{*} \\
(0.78)\end{array}$ & $\begin{array}{c}0.0002^{*} \\
(-1.36)\end{array}$ & $\begin{array}{c}0.0001 \\
(0.67)\end{array}$ & $\begin{array}{c}-0.0001 \\
(-1.30)\end{array}$ & $\begin{array}{l}0.0000 \\
(0.05)\end{array}$ \\
\hline Missing Adv & $\begin{array}{l}0.0001 \\
(1.29)\end{array}$ & $\begin{array}{c}0.0004^{*} \\
(1.71)\end{array}$ & $\begin{array}{c}0.0002^{*} \\
(1.95)\end{array}$ & $\begin{array}{l}0.140^{*} \\
(1.79)\end{array}$ & $\begin{array}{l}0.0386 \\
(0.65)\end{array}$ & $\begin{array}{l}0.103^{*} \\
(1.80)\end{array}$ \\
\hline Intercept & Yes & Yes & Yes & Yes & Yes & Yes \\
\hline $\mathrm{N}$ & 3,853 & 2,365 & 6,218 & 3,271 & 2,420 & 5,691 \\
\hline Adjusted R-squared & 0.403 & 0.285 & 0.315 & 0.32 & 0.322 & 0.266 \\
\hline
\end{tabular}

This panel reports results from an OLS regression of Tobin's $Q$ on past history of merger and acquisition in addition to firm characteristics. Tobin's $Q$ is the sum of market value of equity, liquidation value of preferred equity and book value of total liabilities scaled by total assets. Sales is logged annual sales number. $\mathrm{RD}$ is annual research and development expenditure scaled by PPE. Adv is annual advertising expense scaled by PPE. Capex is annual capital expenditure scaled by PPE. Margin is the ratio of operating income before depreciation to sales. Leverage is market leverage defined as total debt over the sum of total debt and the market value of equity. $\mathrm{K}$ is property, plant, and equipment scaled by sales. Missing RD (Missing Adv) takes one if the annual RD (Adv) is missing and zero otherwise. Incidence is weighted average negative performance incidence defined in the main text. Positive FCF is a dummy variable and takes one if the free 
cash flow measured as in Richardson (2006) is positive and zero otherwise. All standard errors are two-way clustered by both firm and year. T-statistics are presented underneath the coefficient estimates and *****, and * indicate that estimates are significantly different from zero (two-tailed test) at 1\%, 5\%, and $10 \%$ level, respectively.

Panel B: The Coefficient Estimates of Incidence in FCF Quintiles

\begin{tabular}{lccccc}
\hline \hline & Lowest FCF Quintile & Quintile 2 & Quintile 3 & Quintile 4 & Highest FCF Quintile \\
\hline Incidence & 0.013 & -0.013 & -0.008 & $-0.120^{* *}$ & $-0.333^{* * *}$ \\
t-statistics & $(0.20)$ & $(-0.33)$ & $(-0.20)$ & $(-2.31)$ & $(-3.05)$ \\
\hline \hline
\end{tabular}

This panel reports the coefficient estimates of Incidence from an OLS regression of Tobin's Q on Incidence and other firm characteristics by FCF quintiles. All variables are defined in the same way as in Table 4 Panel A. The coefficient estimates of other firm characteristics variables are included in the regression but not shown in this panel for the sake of brevity. T-statistics are presented underneath the coefficient estimates and ${ }^{* *}, * *$, and $*$ indicate that estimates are significantly different from zero at $1 \%, 5 \%$, and $10 \%$ level, respectively.

Panel C: The Effects of Corporate Governance, Earnings Quality, and CEO Turnover

\begin{tabular}{|c|c|c|c|c|c|c|}
\hline & $(1)$ & (2) & (3) & (4) & (5) & (6) \\
\hline & $\mathrm{FCF}>=0$ & $\mathrm{FCF}<0$ & $\mathrm{FCF}>=0$ & $\mathrm{FCF}<0$ & FCF $>=0$ & $\mathrm{FCF}<0$ \\
\hline Incidence & $\begin{array}{l}-0.188^{* *} \\
(-2.02)\end{array}$ & $\begin{array}{c}-0.00906 \\
(-0.15)\end{array}$ & $\begin{array}{l}-0.243^{* *} \\
(-2.52)\end{array}$ & $\begin{array}{l}-0.009 \\
(-0.12)\end{array}$ & $\begin{array}{l}-0.242^{* *} \\
(-2.47)\end{array}$ & $\begin{array}{l}-0.0109 \\
(-0.11)\end{array}$ \\
\hline Governance & $\begin{array}{l}-0.0153 \\
(-0.16)\end{array}$ & $\begin{array}{c}0.0180 \\
(0.23)\end{array}$ & & & & \\
\hline Incidence ${ }^{*}$ Governance & $\begin{array}{c}0.0200 \\
(0.17)\end{array}$ & $\begin{array}{c}-0.0924 \\
(-0.98)\end{array}$ & & & & \\
\hline Quality & & & $\begin{array}{c}-0.200^{* *} \\
(-2.04)\end{array}$ & $\begin{array}{c}0.0344 \\
(0.50)\end{array}$ & & \\
\hline Incidence ${ }^{*}$ Quality & & & $\begin{array}{l}0.118 \\
(1.05)\end{array}$ & $\begin{array}{l}-0.0595 \\
(-0.66)\end{array}$ & & \\
\hline Turnover & & & & & $\begin{array}{c}-0.0248 \\
(-0.33)\end{array}$ & $\begin{array}{r}-0.0449 \\
(-0.78)\end{array}$ \\
\hline Incidence * Turnover & & & & & $\begin{array}{l}0.131 \\
(1.21)\end{array}$ & $\begin{array}{l}-0.0722 \\
(-0.78)\end{array}$ \\
\hline Control variables & Yes & Yes & Yes & Yes & Yes & Yes \\
\hline
\end{tabular}

This panel reports results from an OLS regression of Tobin's $Q$ on past history of merger and acquisition in addition to firm characteristics. This table reports results from an OLS regression of Tobin's Q on past history of merger and acquisition in addition to firm characteristics. Governance takes one if the G-index from Gompers et al. (2003) is lower than the annual sample median and zero otherwise. Quality takes one if the earnings quality measure (proxied by accruals quality (AQ) where higher AQ means poorer quality) is lower than the annual sample median and zero otherwise. Turnover takes one if a firm has changed its CEO over the ten-year rolling window and zero otherwise. The coefficient estimates of other firm characteristics 
variables are included in the regression but not shown in this panel for the sake of brevity. All standard errors are two-way clustered by both firm and year. T-statistics are presented underneath the coefficient estimates and ${ }^{* * *},{ }^{* *}$, and ${ }^{*}$ indicate that estimates are significantly different from zero at $1 \%, 5 \%$, and $10 \%$ level, respectively.

Table 4, Panel A presents the OLS regression results. Consistent with H1, Column (1) shows that the coefficient estimate on Incidence in the positive FCF sample is negative at -0.179 and is statistically significant at less than the $1 \%$ level $(t$-statistic $=-3.42)$. In contrast, in Column (2), the coefficient on Incidence in the negative FCF sample is not significantly different from zero at conventional significance levels $(\beta=-0.013, t$-statistic $=$ 0.28). These results indicate that when the likelihood of attempting future M\&As is high (suggested by having positive free cash flow, i.e., the firm is likely to invest higher than predicted levels), investors place a higher discount on firm value for firms with histories of value-destroying M\&As. However, when firms are less likely to attempt M\&As (as proxied by negative free cash flow, i.e., the firm is unlikely to invest higher than predicted levels), firm value is not sensitive to its over-investment histories. On average, among firms with positive free cash flow, firm value decreases by 0.179 when moving from firms with the best history achievable (Incidence $=0$ ) to firms with the worst history (Incidence $=1$ ). The discount is economically significant, representing $10 \%$ of the average Tobin's Q (1.81) in the positive FCF sample. When the regression is estimated on the full sample in Column (3), the interaction between Positive FCF and Incidence is negative and statistically significant $(\beta=-0.290, t$-statistic $=-3.58)$, emphasizing that it is the combination of both anticipated likelihood and the over-investment history that matter in the firm value discount. To summarize, these findings are consistent with investors forming expectations about the profitability of future M\&A investment decisions based on the 
realized performance outcomes of their past acquisitions and valuing these firms accordingly based on the likelihood of these firms engaging in future acquisitions.

The dependent variable in Table 4 is firms' valuations at least three years after their most recent completed acquisitions. A potential concern for my research design is that the observed relation between Incidence and Tobin's $Q$ may be driven by a mechanical relation between previous stock market performance and future firm values in that the stock return underperformance may affect future firm values, resulting in lowered Tobin's $Q$ at the time of my analysis. ${ }^{3}$ This explanation would otherwise predict a negative relation between Tobin's $Q$ and Incidence for all firms, both positive FCF and negative FCF samples. In contrast, Table 4, Panel A shows that this is not the case. Incidence is negatively related to Tobin's $Q$ only for firms with positive free cash flow.

To further establish that results in Table 4, Panel A are not simply capturing a mechanical relation between past stock returns and current valuations, I conduct a falsification analysis on a matched sample. Specifically, I match each M\&A firm with a non-M\&A firm with the closest market capitalization in the same Fama-French (1997) 48-industry from the entire Compustat database at the time of its first M\&A. I use the actual M\&A announcement date and completion date as the pseudo-dates for the matched non-M\&A firm. For each non-M\&A firm, I calculate Incidence the same way as described in Section 3.2 but using pseudo dates and the returns of the non-M\&A match firm. Therefore, Incidence captures the stock performance of the matched sample the

\footnotetext{
${ }^{3}$ The mechanical relation is unlikely to be the explanation for results in regressions with control variables as the firm fundamental variables will pick up the effect of acquisition performance on firm values.
} 
same way it does for the sample M\&A firms in years prior to valuation. I estimate equation [4] on this matched sample and present results in Columns (4)-(5), for the matched sample firms with positive FCF and negative FCF, respectively. Unlike that in Column (1), the coefficient estimate for Incidence in Column (4) is statistically indistinguishable from zero at conventional levels on the matched positive FCF sample. When the equation is estimated in the full matched sample, the interaction between Positive FCF and Incidence in Column (6) is not significantly different from zero. These results provide evidence that my findings in Columns (1)-(3) are due to investors' expectation of both the profitability and the likelihood of future acquisitions and not to a mechanical relation between previous stock returns and future firm values.

Table 4, Panel A also reveals that the control variables are related to firm value in manners consistent with prior literature. Specifically, Columns (1) to (6) show that Capex is generally positively and significantly associated with Tobin's $Q$ and Leverage is negatively and significantly associated with Tobin's $Q$. Margin is positively associated with Tobin's $Q$ in the positive FCF sample but not in the negative FCF sample. Lastly, in Columns (3) and (6), the coefficient on Positive FCF is positive and strongly significant ( $t$ statistic $=5.30$ and 4.80 , respectively), suggesting that firms with positive free cash flow are valued higher than firms with negative free cash flow. The difference between Columns (3) and (6) is that the positive effect of FCF on firm value is lower for acquiring firms with poorer histories of post-acquisition performance (Column (3)) but is unaffected by non-acquiring firms' past stock performance (Column (6)). 
Results in Columns (1) to (3) in Panel A are predicated on the assumption that investors assess equal likelihood of future M\&A activities for firms with any amountof positive free cash flow. This assumption can be restrictive in that it ignores the effect of the actual magnitude of free cash flow. To examine the robustness of the discount to this assumption, In Table 4, Panel B, I sort firm-year observations by FCF into five quintiles and re-estimate equation [4] for each FCF quintile. All firm characteristics are included in the regression but I only report the coefficient on Incidence for the sake of brevity. Incidence is insignificantly related to firm value for the three lowest FCF quintiles, but is significantly and negatively related to firm value in the two highest FCF quintiles. The coefficient on Incidence almost decreases monotonically from the lowest FCF quintile to the highest FCF quintile. For firms in the highest FCF quintile, the coefficient estimate for Incidence is -0.333 ( $t$-statistic=-3.05), suggesting that Tobin's $Q$ for firms with the best history (Incidence=0) is significantly higher than for the firm with worst history (Incidence $=1)$ by $15 \%(=0.333 / 2.23$, the sample mean Tobin's $Q$ in the highest FCF quintile, untabulated). These results support the anticipation channel: firm values embed anticipated profitability of future M\&A investments as well as investors' expectations of the likelihood of firms engaging in future M\&A. Past over-investment history is more pertinent to firm valuations when the anticipated likelihood of future acquisitions is high.

So far, I document that investors form expectations about future investment based on past investment outcomes and value firms based on the likelihood of M\&A 
attempts. In Table 4, Panel C, I further explore whether corporate governance and information quality (as captured by firms' accruals quality) have any mitigating effects. The idea is that strong corporate governance may mitigate the agency problem of overinvestment (Richardson (2006)) and high earnings quality may improve firms' investment efficiency by better monitoring managers (Biddle et al. (2009)). Therefore, I consider the effects of corporate governance and earnings quality in the relation between firm values and past over-investment history. In Table 4, Panel C, I interact indicators of corporate governance and earnings quality with the main independent variable Incidence. Governance takes a value of one if a firm-year observation has a G-index below the annual sample median (Gompers et al. (2003)) and zero otherwise. ${ }^{4}$ Quality takes a value of one if the firm-year's accruals quality is below the annual sample median and zero otherwise. Accruals quality is estimated cross-sectionally as in Francis et al. (2005)..$^{5}$ In Columns (1) and (2), I interact Incidence with Governance. As before, the coefficient on Incidence is negative and statistically significant in Column (1), but is insignificantly different from zero in Column (2). The coefficient on Incidence * Governance is positive for the positive FCF sample but is not statistically significant at conventional levels. An F-

\footnotetext{
${ }^{4}$ The corporate governance index from Gompers et al. (2003) is constructed from Investor Responsibility Research Center (IRRC, now RiskMetrics). Specifically, they construct their indices based on 24 antitakeover provisions. They add one point for each provision that enhances managerial power to arrive at a comprehensive index for each firm-year. Higher index indicates weaker corporate governance. As discussed in Masulis et al. (2007), IRRC publishes volumes every six years from 1990. I assume that between each consecutive IRRC publication, a firm's corporate governance provisions remain the same as the previous publication year. Empirical results, however, are not sensitive to this assumption.

${ }^{5}$ Specifically, I estimate accruals quality following Francis et al. (2005). Specifically, I estimate $T C A_{j, t}=$ $\phi_{0}+\phi_{1} C F O_{j, t-1}+\phi_{2} C F O_{j, t}+\phi_{3} C F O_{j, t+1}+\phi_{4} \triangle R e v_{j, t}+\phi_{5} P P E_{j, t}+v_{j, t}$ in each Fama-French 48-industry. TCA is total current accruals. CFO is cash flow from operations. $\triangle R e v$ is change in revenues. PPE is property, plant and equipment. All variables are scaled by average total assets. Accruals quality is the five-year rolling standard deviation of firm $j$ 's residuals, $v j, t$ calculated over years $t-4$ through $t$. Larger standard deviations of residuals indicate poorer accruals quality.
} 
test shows that the sum of the coefficients on Incidence and Incidence * Governance is statistically significantly different from zero ( $p$-value=0.06). The coefficient on Incidence is negative and statistically significant in Column (3), but insignificantly different from zero in Column (4). The coefficient on Incidence ${ }^{*}$ Quality is positive for the positive FCF sample but is not statistically significant at conventional levels. An F-test shows that the sum of the coefficients on Incidence and Incidence * Quality is statistically different from zero $(p$-value $=0.04)$. Taken together, I find that strong corporate governance structure or good earnings quality, at best, weakly mitigates the discount caused by past overinvestment for positive FCF firms through the anticipation effect. ${ }^{6}$

Results in Panel A show that firm value is related to past over-investment through investors' anticipation of future investments. Prior research finds that CEOs play a significant role in firms' investment strategies (Malmendier and Tate (2008)). To the extent that a firm may replace its CEO after its value-destroying acquisitions (Lehn and Zhao (2006)), I further explore whether CEO turnover has any mitigating effect using a subsample of firms with available CEO data from the Executive Compensation database (ExecuComp). ${ }^{7}$ Turnover takes a value of one if a firm changed its CEO during the ten-year rolling window and zero otherwise. I interact Incidence with Turnover and present results in Columns (5) and (6). The coefficient on Incidence is negative and statistically significant in Column (5), but is insignificant from zero in Column (6). The

\footnotetext{
${ }^{6}$ I also use the entrenchment-index constructed by Bebchuk et al. (2009). The results are qualitatively similar. ${ }^{7}$ I acknowledge the limitation to the generalizability of the mitigating effect of CEO turnover. Compustat ExecuComp database covers executive compensation data for S\&P 1500 firms from 1992. As I require tenyear's data to calculate Incidence, I use firm-year observations after 2002 with available CEO data in this test. The reported results are biased toward large firms and recent years.
} 
coefficient on Incidence * Turnover is positive for the positive FCF sample (Column (5)) but is not statistically significantly different from zero at conventional levels. An F-test shows that the sum of the coefficients on Incidence and Incidence * Turnover is statistically different from zero ( $p$-value $=0.08)$. Although the firm value discount is still statistically significant even for firms with CEO replacement, the economic magnitude of the discount with CEO replacement shrinks by more than $50 \%$, from 0.24 to 0.11 . This is consistent with investors relying less on histories of over-investment for firms with CEO replacement. To summarize, I conclude that CEO replacement, weakly mitigates the anticipated firm value discount for future investments based on the history of overinvestment in M\&A.

\subsection{Channels of the discount: marginal value of cash holdings}

The previous discussion addresses the relation between future firm values and past M\&A performance. $\mathrm{H} 2$ directly assesses investors' valuation of firms' cash holdings. I estimate the marginal value of cash using the specification in Faulkender and Wang (2006):

$r_{i, t}-r_{i, t}^{b}=\alpha+\beta_{1} \Delta$ Cash $_{t}+\beta_{2} \Delta$ Cash $_{t} *$ Incidence $\beta_{3} \Delta N A_{t}+\beta_{4} \Delta N A_{t} *$ Incidence $+\beta_{5}$ Cash $_{t-1}+\beta_{6} \Delta E_{t}+\beta_{7} \Delta R D_{t}$

$+\beta_{8} \Delta$ Interest $+\beta_{9} \Delta$ Div $+\beta_{10} N F_{t}+\beta_{11}$ Leverage $_{t}+\beta_{12}$ Cash $_{t-1} * \Delta$ Cash $_{t}+\beta_{13}$ Leverage $_{t} * \Delta$ Cash $_{t}+\beta_{14}$ Incidence $u_{i, t}$ 
Table 5: Marginal Value of Cash

\begin{tabular}{|c|c|c|c|c|c|c|}
\hline & $(1)$ & $(2)$ & (3) & $(4)$ & $(5)$ & $(6)$ \\
\hline & $\mathrm{FCF}>=0$ & $\mathrm{FCF}<0$ & $\mathrm{FCF}>=0$ & $\mathrm{FCF}<0$ & $\Delta$ Cash $^{\text {Unexpected }}>=0$ & $\Delta$ Cash $^{\text {Unexpected }}<0$ \\
\hline$\Delta$ Cash & $\begin{array}{c}2.216^{* * *} \\
(3.54)\end{array}$ & $\begin{array}{c}1.120^{* *} \\
(2.03)\end{array}$ & & & & \\
\hline$\Delta$ Cash $^{\text {Expected }}$ & & & $\begin{array}{c}1.957^{* * *} \\
(3.02)\end{array}$ & $\begin{array}{c}1.391^{* *} \\
(2.19)\end{array}$ & $\begin{array}{c}1.432^{* * *} \\
(2.60)\end{array}$ & $\begin{array}{l}0.586 \\
(0.65)\end{array}$ \\
\hline$\Delta$ Cash $^{\text {UnExpected }}$ & & & $\begin{array}{c}2.067^{* * *} \\
(4.04)\end{array}$ & $\begin{array}{l}0.676 \\
(1.44)\end{array}$ & $\begin{array}{c}1.707^{* * *} \\
(5.79)\end{array}$ & $\begin{array}{l}1.340 \\
(1.49)\end{array}$ \\
\hline Incidence $^{*} \Delta$ Cash & $\begin{array}{c}-0.867^{* *} \\
(-1.97)\end{array}$ & $\begin{array}{l}-0.219 \\
(-0.56)\end{array}$ & & & & \\
\hline Incidence ${ }^{*} \Delta$ Cash $^{\text {Expected }}$ & & & $\begin{array}{l}-0.563 \\
(-1.26)\end{array}$ & $\begin{array}{c}0.0552 \\
(0.14)\end{array}$ & $\begin{array}{l}-0.130 \\
(-0.73)\end{array}$ & $\begin{array}{c}-0.00463 \\
(-0.01)\end{array}$ \\
\hline Incidence ${ }^{*} \Delta$ Cash $^{\text {Unexpected }}$ & & & $\begin{array}{c}-0.877^{* *} \\
(-2.48)\end{array}$ & $\begin{array}{l}-0.350 \\
(-0.76)\end{array}$ & $\begin{array}{c}-0.499^{* *} \\
(-2.33)\end{array}$ & $\begin{array}{l}-0.776 \\
(-1.41)\end{array}$ \\
\hline$\triangle \mathrm{NA}$ & $\begin{array}{c}0.166^{* * *} \\
(2.93)\end{array}$ & $\begin{array}{c}0.275^{* * *} \\
(4.98)\end{array}$ & $\begin{array}{c}0.173^{* * *} \\
(3.22)\end{array}$ & $\begin{array}{c}0.294^{* * *} \\
(5.22)\end{array}$ & $\begin{array}{c}0.251^{* * *} \\
(4.35)\end{array}$ & $\begin{array}{l}0.157 \\
(1.64)\end{array}$ \\
\hline Incidence $^{*} \Delta \mathrm{NA}$ & $\begin{array}{c}-0.0383 \\
(-0.47)\end{array}$ & $\begin{array}{c}-0.0224 \\
(-0.30)\end{array}$ & $\begin{array}{c}-0.0449 \\
(-0.55)\end{array}$ & $\begin{array}{c}-0.0358 \\
(-0.48)\end{array}$ & $\begin{array}{l}-0.121 \\
(-1.46)\end{array}$ & $\begin{array}{l}0.106 \\
(0.77)\end{array}$ \\
\hline$\Delta \mathrm{E}$ & $\begin{array}{c}0.642^{* * *} \\
(5.42)\end{array}$ & $\begin{array}{c}0.503^{* * *} \\
(3.56)\end{array}$ & $\begin{array}{c}0.656^{* * *} \\
(5.19)\end{array}$ & $\begin{array}{c}0.473^{* * *} \\
(3.08)\end{array}$ & $\begin{array}{c}0.644^{* * *} \\
(3.94)\end{array}$ & $\begin{array}{c}0.552^{* * *} \\
(6.50)\end{array}$ \\
\hline$\Delta \mathrm{RD}$ & $\begin{array}{l}0.452 \\
(0.41)\end{array}$ & $\begin{array}{l}-0.585 \\
(-0.41)\end{array}$ & $\begin{array}{l}0.709 \\
(0.67)\end{array}$ & $\begin{array}{l}-0.431 \\
(-0.35)\end{array}$ & $\begin{array}{c}-0.0921 \\
(-0.10)\end{array}$ & $\begin{array}{l}1.000 \\
(0.85)\end{array}$ \\
\hline$\Delta$ Interest & $\begin{array}{c}-2.220^{* * *} \\
(-3.53)\end{array}$ & $\begin{array}{c}-2.340^{*} \\
(-1.85)\end{array}$ & $\begin{array}{c}-2.347^{* * *} \\
(-3.92)\end{array}$ & $\begin{array}{c}-2.353^{*} \\
(-1.85)\end{array}$ & $\begin{array}{c}-2.053^{* *} \\
(-2.28)\end{array}$ & $\begin{array}{c}-3.715^{* * *} \\
(-3.17)\end{array}$ \\
\hline$\Delta$ Div & $\begin{array}{c}0.557^{* * *} \\
(3.68)\end{array}$ & $\begin{array}{c}0.0611 \\
(0.27)\end{array}$ & $\begin{array}{c}0.527^{* * *} \\
(3.56)\end{array}$ & $\begin{array}{l}0.130 \\
(0.62)\end{array}$ & $\begin{array}{c}0.458^{* * *} \\
(3.57)\end{array}$ & $\begin{array}{c}-0.583^{*} \\
(-1.87)\end{array}$ \\
\hline NF & $\begin{array}{c}1.150^{* * *} \\
(3.67)\end{array}$ & $\begin{array}{c}1.108^{* *} \\
(2.52)\end{array}$ & $\begin{array}{c}1.135^{* * *} \\
(3.60)\end{array}$ & $\begin{array}{c}1.142^{* * *} \\
(3.01)\end{array}$ & $\begin{array}{c}0.836^{* * *} \\
(2.68)\end{array}$ & $\begin{array}{c}1.053^{* * *} \\
(2.88)\end{array}$ \\
\hline Lev & $\begin{array}{c}-0.335^{* * *} \\
(-6.54)\end{array}$ & $\begin{array}{c}-0.463^{* * *} \\
(-3.59)\end{array}$ & $\begin{array}{c}-0.333^{* * *} \\
(-6.96)\end{array}$ & $\begin{array}{c}-0.487^{* * *} \\
(-3.40)\end{array}$ & $\begin{array}{c}-0.327^{* * *} \\
(-3.30)\end{array}$ & $\begin{array}{c}-0.532^{* * *} \\
(-7.09)\end{array}$ \\
\hline Casht-1 & $\begin{array}{c}0.414^{* * *} \\
(3.19)\end{array}$ & $\begin{array}{c}0.191^{* *} \\
(2.35)\end{array}$ & $\begin{array}{l}0.169 \\
(0.62)\end{array}$ & $\begin{array}{l}0.927 \\
(1.04)\end{array}$ & $\begin{array}{l}0.302 \\
(0.50)\end{array}$ & $\begin{array}{l}0.129 \\
(0.26)\end{array}$ \\
\hline Leverage $^{*} \Delta$ Cash & $\begin{array}{c}-2.235^{* * *} \\
(-3.21)\end{array}$ & $\begin{array}{l}-0.585 \\
(-1.10)\end{array}$ & & & & \\
\hline $\operatorname{Cash}_{t-1}^{*} \Delta$ Cash & $\begin{array}{c}-1.523^{* *} \\
(-2.02)\end{array}$ & $\begin{array}{l}-1.166 \\
(-1.20)\end{array}$ & & & & \\
\hline $\operatorname{Cash}_{t-1}{ }^{*} \Delta$ Cash $^{\text {Expected }}$ & & & $\begin{array}{c}-1.402^{*} \\
(-1.91)\end{array}$ & $\begin{array}{l}0.194 \\
(0.29)\end{array}$ & $\begin{array}{c}0.0414 \\
(0.10)\end{array}$ & $\begin{array}{l}-2.284 \\
(-1.21)\end{array}$ \\
\hline $\operatorname{Cash}_{t-1}{ }^{*} \Delta$ Cash Unexpected & & & $\begin{array}{l}-0.620 \\
(-1.20)\end{array}$ & $\begin{array}{c}0.0794 \\
(0.11)\end{array}$ & $\begin{array}{l}-0.108 \\
(-0.38)\end{array}$ & $\begin{array}{l}-4.131 \\
(-0.45)\end{array}$ \\
\hline $\operatorname{Lev}^{*} \Delta$ Cash $^{\text {Expected }}$ & & & $\begin{array}{c}-1.981^{* *} \\
(-2.47)\end{array}$ & $\begin{array}{l}-0.585 \\
(-1.30)\end{array}$ & $\begin{array}{c}-1.673^{* * *} \\
(-4.15)\end{array}$ & $\begin{array}{l}1.050 \\
(0.89)\end{array}$ \\
\hline $\operatorname{Lev}^{*} \Delta$ Cash Unexpected & & & $\begin{array}{c}-2.111^{* * *} \\
(-3.20)\end{array}$ & $\begin{array}{l}-0.280 \\
(-0.59)\end{array}$ & $\begin{array}{c}-1.869^{* * *} \\
(-4.09)\end{array}$ & $\begin{array}{l}0.132 \\
(0.07)\end{array}$ \\
\hline Incidence & $\begin{array}{l}-0.000 \\
(-0.00)\end{array}$ & $\begin{array}{c}0.0132 \\
(0.66)\end{array}$ & $\begin{array}{c}0.0109 \\
(0.72)\end{array}$ & $\begin{array}{c}0.0374^{*} \\
(1.75)\end{array}$ & $\begin{array}{c}0.0297 \\
(1.21)\end{array}$ & $\begin{array}{c}-0.0558 \\
(-1.15)\end{array}$ \\
\hline Interest & Yes & Yes & Yes & Yes & Yes & Yes \\
\hline $\mathrm{N}$ & 3,758 & 2,275 & 3,758 & 2,275 & 3,158 & 2,875 \\
\hline Adjusted R-squared & 0.165 & 0.133 & 0.168 & 0.136 & 0.142 & 0.146 \\
\hline
\end{tabular}


This table reports results from an OLS regression of annual stock returns on past history plus firm characteristics. The dependent variable $R_{i}-R_{b}$ is the size and book-to-market adjusted compounded annual realized returns from fiscal year $t-1$ to $t$. Incidence is weighted average negative performance incidence defined in the main text. $\Delta$ Cash is the change in cash. $\Delta$ Cash Expected is the change in expected cash. $\Delta$ Cash $^{\text {Excess }}$ is the change in unexpected cash. Casht-1 is cash balance from last year. $\Delta \mathrm{E}$ is the change in earnings before extraordinary items plus interest, deferred tax credits, and investment tax credits. $\Delta \mathrm{NA}$ is the change in net assets where net assets are defined as total assets minus cash holdings. $\Delta$ Interest is the change in interest expense. $\Delta \mathrm{Div}$ is the change in common dividends paid. Leverage is the market leverage defined as total debt over the sum of total debt and the market value of equity. NF is the total equity issuance minus repurchases plus debt issuance minus debt redemption. $\triangle \mathrm{RD}$ is the change in $\mathrm{R} \& \mathrm{D}$ expenditures. All independent variables except Leverage and Incidence are deflated by the lagged market value of equity. All standard errors are two-way clustered by both firm and year. T-statistics are presented underneath the coefficient estimates and $* * * *$, and $*$ indicate that estimates are significantly different from zero at $1 \%, 5 \%$, and $10 \%$ level, respectively.

The dependent variable $r_{i, t}-r_{i, t^{b}}$ is the compounded size and book-to-market adjusted realized returns from fiscal year $t-1$ to $t . \Delta$ Cash is the change in cash. Casht $t_{t-1}$ is the cash balance from last year. $\Delta E$ is the change in earnings before extraordinary items plus interest, deferred tax credits, and investment tax credits. $\triangle N A$ is the change in net assets, where net assets are defined as total assets minus cash holdings. IInterest is the change in interest expense. $\Delta$ Div is the change in common dividends paid. Leverage is total debt over the sum of total debt and the market value of equity. NF is the total equity issuance minus repurchases plus debt issuance minus debt redemption. $\Delta R D$ is the change in R\&D expenditures. All independent variables except Leverage and Incidence are deflated by the market value of equity in year $t-1$. This deflation allows the coefficient estimates to be interpreted as the marginal values of the right-hand-side variables. I interact Incidence with $\Delta$ Cash to examine whether investors place a discount on the marginal cash holdings of firms with over-investment histories. I also interact Incidence with $\triangle N A$ to ascertain whether there is an associated discount on noncash assets. 
Table 5 presents the OLS regression results. The main variable of interest is the interaction term between Incidence and $\Delta$ Cash. In Columns (1) and (2), I estimate equation [5] separately for the positive and negative FCF samples. The coefficients on $\Delta$ Cash are 2.216 and 1.120 for the positive and negative FCF samples, respectively. This means that on average, in the absence of past over-investment, each additional dollar held by a firm with zero cash and no leverage is valued by investors at $\$ 2.216$ and $\$ 1.120$ for the positive FCF and negative samples, respectively. This contrast is consistent with intuitions from stock valuation that on average, firms generating positive free cash flow have higher marginal values of cash than those generating negative free cash flow in absence of past over-investment history. Most importantly, for the positive FCF sample, the coefficient on the interaction between Incidence and $\triangle$ Cash is negative and is statistically significant at the $5 \%$ level in Column (1). The discount in marginal cash valuation is also economically significant, indicating that among firms with positive free cash flow, an additional dollar of cash is valued 87 cents less for firms with the worst history of value-destroying acquisitions compared with firms with the best history. However, the interaction term is indistinguishable from zero at conventional significance levels in Column (2) for the negative FCF sample. Coefficients on $\triangle N A$ and $\Delta E$ are generally positive and significant in both columns, consistent with investors assigning higher values for firms with strong balance sheet asset positions and net earnings growth. Results for other control variables are also similar to findings in Faulkender and Wang (2006). 
The analysis in Table 4 Panel A shows that in the positive FCF sample, moving from a firm with the best past history to a firm with the worst history results in a decrease in Tobin's $Q$ of 0.179 . Assuming that the marginal value of cash is a good proxy for the average value of cash, the result in Column (1) indicates that around $80 \%$ $\left(\left(0.867^{*}\left(\triangle \text { Cash }_{t}+\text { Cash }_{t-1}\right)^{*} M V E /\right.\right.$ Total assets $) / 0.179$, all expressed in the positive FCF sample averages) of the discount in Tobin's $Q$ documented in Table 4 is due to the discount in cash holdings. This is consistent with $\mathrm{H} 2$ in that when the likelihood of future acquisition using cash is high, investors discount the value of marginal cash for firms with anticipated unprofitable M\&As. In contrast, the coefficient on the interaction between Incidence and $\triangle N A$ in Column (1) is insignificant from zero, suggesting that the marginal value of noncash assets is not discounted by investors for firms with anticipated value-destroying M\&As. This is consistent with theoretical predictions in Myers and Majluf (1984) and Myers and Rajan (1998) that noncash assets are less likely to subject to tunneling risk than cash assets.

To further study investors' differential pricing of marginal value of cash, I decompose the change in cash balance into an expected component and an unexpected component in Columns (3) and (4), whereas the expected component captures cash required due to firms' normal, expected levels of operating, investing and financing needs. To predict future cash balance, I adopt the modified Opler et al. (1999) model to estimate the optimal cash balance using last year's financial variables. 
$\ln (\text { Cash })_{i, t}=\alpha+\beta_{1} \ln (M V E)_{i, t-1}+\beta_{2}$ Growth $_{i, t-1}+\beta_{3} C F_{i, t-1}+\beta_{4} N W C A P_{i, t-1}+\beta_{5} C A P X_{i, t-1}+\beta_{6} D_{e b t} t_{i,-1}+\beta_{7} R D_{i, t-}$

$$
{ }_{1}+\beta{ }_{8} D D_{i v i},-1+u_{i, t}[6]
$$

MVE is the market value of equity; Growth is sales growth; $C F$ is operating income less interest, taxes, and common dividends scaled by the market value of equity in year $t-1$; NWCAP is net non-cash working capital scaled by the market value of equity in year $t-1$; CAPX is capital expenditures scaled by the market value of equity in year $t-1$; Debt is total debt calculated as long-term debt plus the current portion of long-term debt scaled by the market value of equity in year $t-1 ; R D$ is research and development expenses scaled by the market value of equity in year $t-1$; and $D D I V$ is a dummy variable that is set to one if the firm pays dividends and zero otherwise. Equation [6] is estimated separately for each of the Fama-French 48 industries (1997) in the entire Compustat population. I apply the coefficient estimates to my sample firms and use the fitted values as the predicted value of next-year's normal level of cash balance. The difference between the predicted cash and observed cash balance is the change in unexpected cash. The difference between predicted cash and last period's cash is the change in expected cash. I then re-estimate equation [5] by decomposing $\Delta$ Cash into the change in expected $\operatorname{cash}\left(\Delta \operatorname{Cash}^{\text {Expected }}\right)$ and the change in unexpected $\operatorname{cash}\left(\Delta \operatorname{Cash}^{\text {Unexpected }}\right)$.

Columns (3) and (4) of Table 5 report the results from decomposing $\Delta$ Cash into $\Delta$ Cash $^{\text {Expected }}$ and $\Delta$ Cash $^{\text {Unexpected }}$ for the positive FCF and negative FCF samples, respectively. The coefficient on Incidence ${ }^{*}$ Cash $^{\text {Unexpected }}$ is negative and statistically significant only in the positive FCF sample. The coefficient on Incidence ${ }^{*}$ Cash $^{\text {Expected }}$ is not significantly different from zero in either column. The magnitude of the discount is also economically 
significant: one dollar of unexpected cash is valued 88 cents lower by investors for firms with the worst history of over-investment than firms with the best history. Taken together, this suggests that the discount on the marginal value of cash that we observed in Column (1) comes mainly from the unexpected portion of cash.

$\Delta$ Cash $^{\text {Unexpected }}$ in Columns (3) and (4) is the residual term from equation [6]. As it can be both positive (excess cash) and negative (shortage in cash), I further ensure that my results capture investors' discount on excess cash. I partition my sample into firms that have excess cash and firms that have a cash shortage and re-estimate the decomposed version of equation [5]. Results are presented in Columns (5) and (6). As predicted, the coefficient on Incidence ${ }^{*} \Delta$ Cash $^{\text {Unexpected }}$ is only negative and statistically significant for the excess cash sample, consistent with investors placing a discount on firms with managers extracting rents from cash beyond what is expected for these firms. Firm characteristics in Columns (2) through (6) are estimated similarly as in Column (1). In almost all columns, the coefficient of Incidence itself is not statistically significant from zero at conventional levels. Taken together, I find that investors place a discount on a firm's marginal value of cash for firms with histories of value-destroying acquisitions when the likelihood of future M\&As is high, and this discount is mainly on the firm's excess cash that is unexpected given the firm's business model.

\subsection{Channels of the discount: information uncertainty}

Erickson et al. (2012) find that for acquiring firms, analysts' forecast dispersion after acquisitions is negatively associated with post-acquisition returns. They interpret 
their findings as consistent with the idea that acquisitions increase investors' uncertainty about future earnings, which leads to a higher cost of capital and therefore lower market valuation. In H3, I further examine whether the anticipation effect affects firm value through the discount rate channel in anticipating possible acquisitions. I conduct my analysis using a subsample of firms followed by at least three analysts. As in Erickson et al. (2012), I use analyst forecast dispersion as a proxy for information uncertainty. I estimate analyst forecast dispersion as a function of firm characteristics and Incidence as follows:

Dispersioni,

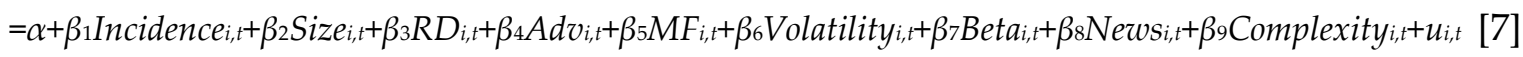

The dependent variable Dispersion is the standard deviation of IBES analysts' one-year ahead annual EPS forecasts scaled by the median forecast. ${ }^{8}$ Size is logged total assets. Growth is sales growth. MF is the number of management earnings forecasts as reported in the First Call database. Volatility is the standard deviation of the firm's monthly stock returns from the previous fiscal year. Beta is the CAPM beta estimated using monthly returns over a ten-year rolling window. News is the absolute value of the cumulative market-adjusted returns around the 10-K filing event window [-1, 1]. Complexity is the logged number of operating segments reported in Compustat. $R D$, Advertising and Positive FCF are defined as above.

${ }^{8}$ I scale the standard deviation of EPS forecasts by the median forecast. An alternative is to scale the standard deviation by share price. However, my previous analysis shows that share prices are lower for firms with over-investment histories when they have positive free cash flow. Therefore, to make sure that the relation between the dispersion variable and M\&A history is not driven by the scaling variable, I use the median forecast as the scalar. 
Table 6: Information Uncertainty

\begin{tabular}{|c|c|c|c|}
\hline & $(1)$ & $(2)$ & $(3)$ \\
\hline & $\mathrm{FCF}>=0$ & $\mathrm{FCF}<0$ & Full sample \\
\hline Incidence & $\begin{array}{c}0.0295^{* *} \\
(2.26)\end{array}$ & $\begin{array}{c}0.00421 \\
(0.12)\end{array}$ & $\begin{array}{c}-0.00152 \\
(-0.06)\end{array}$ \\
\hline Positive FCF & & & $\begin{array}{c}-0.0644^{* * *} \\
(-2.82)\end{array}$ \\
\hline Incidence ${ }^{*}$ Positive FCF & & & $\begin{array}{c}0.0361 \\
(1.13)\end{array}$ \\
\hline Size & $\begin{array}{c}0.00489 \\
(1.13)\end{array}$ & $\begin{array}{c}-0.00241 \\
(-0.20)\end{array}$ & $\begin{array}{c}0.00154 \\
(0.30)\end{array}$ \\
\hline R\&D & $\begin{array}{c}0.0264^{* * *} \\
(3.18)\end{array}$ & $\begin{array}{c}-0.0562^{* * *} \\
(-2.95)\end{array}$ & $\begin{array}{c}-0.0135 \\
(-1.47)\end{array}$ \\
\hline Adv & $\begin{array}{c}0.0538^{*} \\
(1.82)\end{array}$ & $\begin{array}{c}-0.0763 \\
(-0.98)\end{array}$ & $\begin{array}{c}-0.00421 \\
(-0.12)\end{array}$ \\
\hline Growth & $\begin{array}{c}-0.0997^{* *} \\
(-2.08)\end{array}$ & $\begin{array}{c}-0.0495 \\
(-0.60)\end{array}$ & $\begin{array}{c}-0.0677 \\
(-1.48)\end{array}$ \\
\hline MF & $\begin{array}{c}-0.00969^{* * *} \\
(-3.44)\end{array}$ & $\begin{array}{c}-0.0112 \\
(-1.18)\end{array}$ & $\begin{array}{c}-0.0109^{* * *} \\
(-3.06)\end{array}$ \\
\hline Volatility & $\begin{array}{c}0.939^{* * *} \\
(6.89)\end{array}$ & $\begin{array}{l}0.487 \\
(1.61)\end{array}$ & $\begin{array}{c}0.726^{* * *} \\
(4.88)\end{array}$ \\
\hline News & $\begin{array}{c}0.565^{* * *} \\
(4.01)\end{array}$ & $\begin{array}{l}0.567^{*} \\
(1.79)\end{array}$ & $\begin{array}{c}0.614^{* * *} \\
(3.98)\end{array}$ \\
\hline Complexity & $\begin{array}{c}0.0248^{* *} \\
(2.30)\end{array}$ & $\begin{array}{c}0.0187 \\
(0.55)\end{array}$ & $\begin{array}{c}0.0236^{*} \\
(1.76)\end{array}$ \\
\hline Beta & $\begin{array}{l}0.0113 \\
(0.94)\end{array}$ & $\begin{array}{c}0.0114 \\
(0.38)\end{array}$ & $\begin{array}{c}0.00807 \\
(0.59)\end{array}$ \\
\hline Intercept & Yes & Yes & Yes \\
\hline $\mathrm{N}$ & 2,357 & 1,367 & 3,724 \\
\hline Adjusted R-squared & 0.069 & 0.013 & 0.027 \\
\hline
\end{tabular}

This table reports results from an OLS regression of analyst forecast dispersion on past history plus firm characteristics. The dependent variable is analyst forecast dispersion defined as the standard deviation of analysts' forecasted EPS numbers dividend by the median forecasts. Incidence is weighted average negative performance incidence defined in the main text. Size is logged market value of equity. RD is annual research and development expense scaled by PPE. Adv is annual advertising expense scaled by PPE. Growth is the sales growth. MF is the number of management earnings guidance as reported in the First call database. Volatility is the standard deviation of the firm's monthly stock returns from the previous fiscal year. News is the absolute value of the cumulative market-adjusted return for the $10-\mathrm{K}$ filing event window $[-1,1]$. Complexity is the logged number of operating segments reported in Compustat. Beta is the CAPM beta estimated over the 10-year rolling window. Positive FCF is a dummy variable and takes one if the free cash flow measured as in Richardson (2006) is positive and zero otherwise. All standard errors are two-way clustered by both firm and year. T-statistics are presented underneath the coefficient estimates and ${ }^{* * *}, * *$, and ${ }^{*}$ indicate that estimates are significantly different from zero at $1 \%, 5 \%$, and $10 \%$ level, respectively. 
Table 6 presents the estimation results. The coefficient estimate for Incidence is positive and statistically significant in the positive FCF sample and insignificantly different from zero at conventional significance levels in the negative FCF sample. This indicates that when a firm has positive free cash flow, financial analysts have more degree of uncertainty about future earnings for firms with histories of over-investment. This is consistent with the idea that analysts assign a higher likelihood of engaging in future acquisitions for firms with positive free cash flow. To the extent that these potential future acquisitions will alter a firm's future earnings stream, and that analysts are more uncertain about the performance and profitability of future acquisitions for firms with histories of value-destroying acquisitions, analysts' earnings forecasts will exhibit more dispersion. This could be due to analysts' perception that firms with previous value-destroying M\&As may not carefully select target firms or may not know how to properly integrate and manage the acquired firms. Control variables exhibit similar results as in Lehavy et al. (2012). To summarize, Table 6 shows that likely acquirers with histories of over-investment have more information uncertainty, which in theory would result in a higher cost of capital (Wang (1993)). Viewed together with the results in Table 4, these findings suggest that information uncertainty is a potential contributing factor to low valuations through anticipation for firms with past valuedestroying M\&As.

\subsection{Effect on the announcement window return of future acquisitions}


My previous analysis argues that investors assess a lower likelihood of future M\&As for firms with negative free cash flow. An implication is that when firms with negative free cash flow announce M\&As, the announcements are more likely to be news to investors. To confirm this, I study a smaller sample of firm-year observations that actually announced acquisitions in the future (i.e., during the long window of $[-183,183]$ where day 0 is the earnings announcement date). ${ }^{9} \mathrm{I}$ examine the 5 -day cumulative abnormal return $(C A R)$ around the acquisition announcement window $[-2,+2]$ adjusted by the market model (see M\&A $(n+1)$ in Figure 1). The market model parameters are estimated over the long window $[-210,-11]$ prior to the acquisition announcement.

Table 7, Panel A presents the descriptive statistics for the main dependent variable: 5-day $C A R$ around the acquisition announcement. Consistent with results in Andrade et al. (2001), for the positive FCF sample, the mean of the 5-day CAR is -0.002 and is statistically insignificant from zero $(t=-0.49)$. The anticipation effect documented in the previous section provides a possible explanation for the insignificant or negative announcement window return. When M\&As are expected, the anticipated investment outcomes have been impounded into stock prices prior to the announcements. When likely acquirers announce acquisition plans, the short-window return are no longer sensitive to anticipated investment outcomes as information regarding future investments has already found its way into prices. In contrast, the mean of 5-day $C A R$

\footnotetext{
${ }^{9}$ I select this window to ensure that firms' operations are known or close to known to investors. Consistent with the design choice in Section 3, I require announced acquisitions to be partially cash financed, i.e., the cash payment portion accounts for at least $1 \%$ of the transaction value. Results are similar if I alternatively require cash payment to be at least $5 \%, 10 \%$, or $20 \%$.
} 
for the negative FCF sample is 0.012 and is marginally significant from zero $(t=1.72)$. The difference is statistically significant at the $5 \%$ level $(t=1.98$, untabulated). This comparison suggests that, on average, firms with negative free cash flow experience higher announcement returns than firms with positive free cash flow. ${ }^{10}$ Less anticipated M\&A announcements contain more news to investors, resulting in higher announcement returns.

To formally examine the effect of over-investment history on the stock returns around future M\&A announcement dates (H4), I follow the specification in Masulis et al. (2007) and estimate $C A R$ as a function of firm characteristics and Incidence. ${ }^{11}$

\begin{abstract}
$C A R[-2,+2], i$
$=\alpha+\beta_{1}$ Incidence $i_{i}+\beta_{2}$ Size $_{i, t}+\beta_{3}$ Leverage $_{i, t}+\beta_{4}$ Stock price runup $p_{i, t}+\beta_{5}$ Deal value $i_{i,}+\beta_{6}$ Governance $_{i, t}+\beta_{7}$ Stock $_{i, t}$

$+\beta_{8}$ Public Target ${ }_{i, t}+\beta_{9}$ Stock $_{i, t}{ }^{*}$ Public Target ${ }_{i, t}+\beta_{10}$ Private Target,$t+^{+}+\beta_{11}$ Stock $^{*}$ Private Target,$t+\beta_{12} F C F_{i, t}+u_{, t}$
\end{abstract}

\footnotetext{
${ }^{10}$ Cai et al. (2011) also report that less anticipated bids earn significantly higher announcement returns. They examine how industry merger waves affect acquiring firms' announcement returns. They define anticipated acquirers as bidders in industries where the previous bid was announced less than one year ago. In their framework, the anticipation of future acquisitions works through the information transfer through industry channels. In my design, the anticipation of future acquisitions works through the free cash flow hypothesis.

${ }^{11}$ My last hypothesis (H4) regards investors' initial reaction to the acquisition announcement. The idea is that if an acquisition is expected and information about the anticipated performance implied by the past has already been impounded in firm value, the short-window return around the announcement should not be systematically related to the over-investment history. Therefore, in this test, the announcement return is not meant to capture the acquisition performance. In addition, the announcement return does not necessarily have to be complete to describe effect of the acquisition on investors' wealth. Rather, I use this short-term announcement window to document investors' pricing of an acquisition's anticipated profitability when the announcement has either confirmed or updated investors' judgment of the acquisition likelihood. As of the announcement date, the likelihood of an acquisition has materialized. If investors are surprised at the acquisition announcement, i.e., they have not formed expectation about the acquisition prior to the announcement, they will form expectation about the announced acquisition's profitability based on what they have been observing from the firm's investment history at the announcement window. The above discussion forms the basis of $\mathrm{H} 4$.
} 
Table 7: Announcement Window Return Test

Panel A: Descriptive Statistics of 5-day Announcement Returns

\begin{tabular}{|c|c|c|c|c|c|c|c|c|c|c|}
\hline \multirow[b]{2}{*}{ Variable } & \multicolumn{5}{|c|}{$\mathrm{FCF}>=0($ Positive $\mathrm{FCF}=1)$} & \multicolumn{5}{|c|}{ FCF $<0$ (Positive FCF=0) } \\
\hline & $\mathrm{P} 25$ & Median & P75 & Std Dev & Mean & $\mathrm{P} 25$ & Median & P75 & $\begin{array}{c}\text { Std } \\
\text { Dev }\end{array}$ & Mean \\
\hline \multirow[t]{2}{*}{ CAR } & -0.031 & -0.004 & 0.024 & 0.056 & -0.002 & -0.029 & $0.011^{*}$ & 0.045 & 0.075 & $0.012^{*}$ \\
\hline & & $(-0.73)$ & & & $(-0.49)$ & & $(1.70)$ & & & $(1.72)$ \\
\hline
\end{tabular}

This panel reports the summary statistics of cumulative abnormal return (CAR) over the announcement window $[-2,+2]$ adjusted by the market model. The market model parameters are estimated over the long window [-210, -11]. T-statistics (Z-statistics) for the mean (median) are presented in the parenthesis and ${ }^{* * *}$, **, and * indicate that estimates are significantly different from zero at $1 \%, 5 \%$, and $10 \%$ level, respectively.

Panel B: The Announcement Window Return Test

\begin{tabular}{|c|c|c|}
\hline & (1) & (2) \\
\hline & $\mathrm{FCF}>=0$ & $\mathrm{FCF}<0$ \\
\hline Incidence & $\begin{array}{c}-0.00470 \\
(-0.64)\end{array}$ & $\begin{array}{c}-0.0272^{* *} \\
(-2.44)\end{array}$ \\
\hline Size & $\begin{array}{c}-0.00265^{*} \\
(-1.76)\end{array}$ & $\begin{array}{c}-0.00538 \\
(-1.11)\end{array}$ \\
\hline Leverage & $\begin{array}{c}0.0284 \\
(1.13)\end{array}$ & $\begin{array}{c}0.00457 \\
(0.08)\end{array}$ \\
\hline Stock Price Runup & $\begin{array}{c}-0.0471^{* * *} \\
(-3.18)\end{array}$ & $\begin{array}{c}-0.0973^{* * *} \\
(-3.60)\end{array}$ \\
\hline Deal Value & $\begin{array}{c}0.00611 \\
(0.49)\end{array}$ & $\begin{array}{c}0.0463^{* *} \\
(2.19)\end{array}$ \\
\hline Governance & $\begin{array}{c}0.00170 \\
(0.25)\end{array}$ & $\begin{array}{c}0.0107 \\
(1.22)\end{array}$ \\
\hline Stock & $\begin{array}{c}-0.0462 \\
(-0.83)\end{array}$ & $\begin{array}{c}0.0136 \\
(0.16)\end{array}$ \\
\hline Public Target & $\begin{array}{c}-0.0185^{* *} \\
(-2.53)\end{array}$ & $\begin{array}{c}-0.0161 \\
(-1.60)\end{array}$ \\
\hline Public Target * Stock & $\begin{array}{c}0.0336 \\
(0.60)\end{array}$ & $\begin{array}{c}-0.0683 \\
(-0.77)\end{array}$ \\
\hline Private Target & $\begin{array}{c}-0.0228^{*} \\
(-1.87)\end{array}$ & $\begin{array}{c}-0.0249 \\
(-1.25)\end{array}$ \\
\hline Private Target* & & \\
\hline Stock & $\begin{array}{c}0.0505 \\
(0.89)\end{array}$ & $\begin{array}{c}-0.0190 \\
(-0.22)\end{array}$ \\
\hline FCF & $\begin{array}{c}0.0480 \\
(0.53)\end{array}$ & $\begin{array}{l}-0.105 \\
(-0.92)\end{array}$ \\
\hline Intercept & YES & YES \\
\hline $\mathrm{N}$ & 277 & 113 \\
\hline Adjusted R-squared & 0.076 & 0.324 \\
\hline
\end{tabular}


This panel reports results from an OLS regression of announcement acquirer return on past history and firm characteristics. The dependent variable is cumulative abnormal return (CAR) over the announcement window $[-2,+2]$ adjusted by the market model. The market model parameters are estimated over the long window [-210, -11]. Incidence is weighted average negative performance incidence defined in the main text. Size is the logged total assets. Leverage is market leverage defined as total debt over the sum of total debt and the market value of equity. Stock Price Runup is the market-adjusted buy-and-hold market-adjusted stock return during the long window of $[-210,-11]$. Deal value is the size of the deal defined as the transaction value divided by the acquirer's pre-acquisition market value of equity. Governance takes one if the G-index from Gompers et al. (2003) is lower than the sample median and zero otherwise. Stock takes one if the deal is at least partially stock-financed and zero otherwise. Public Target takes one if the target is a public firm and zero otherwise. Private Target takes one if the target is a private firm and zero otherwise. FCF is free cash flow measured as in Richardson (2006). T-statistics are presented underneath the coefficient estimates and $* * * * *$, and $*$ indicate that estimates are significantly different from zero at $1 \%, 5 \%$, and $10 \%$ level, respectively.

The dependent variable is cumulative abnormal return (CAR). Stock Price Runup

is the market-adjusted buy-and-hold stock return over the long window of [-210, -11]

prior to the acquisition announcement. Deal value is the size of the deal defined as the transaction value divided by the acquirer's pre-acquisition market value of equity. Stock takes a value of one if the deal is at least partially stock-financed and zero otherwise. Public Target takes a value of one if the target is a public firm and zero otherwise. Private Target takes a value of one if the target is a private firm and zero otherwise. Size, Leverage, Governance, Positive FCF are defined the same as above. Incidence is the main variable of interest and is hypothesized to have a negative sign for the negative FCF sample.

Table 7, Panel B presents the OLS regression results. Consistent with the idea that firms with positive free cash flow are more likely to engage in future acquisitions, this subsample consists of 277 firm-year observations with positive free cash flow and 113 firm-year observations with negative free cash flow. Further, Column (1) shows that the coefficient estimate on Incidence is statistically insignificant from zero in the positive FCF sample. In contrast, in Column (2), the coefficient on Incidence is negative and 
statistically significant $(\beta=-0.0272, t$-statistic $=-2.44)$ in the negative FCF sample. Firms with the worst history suffer a drop of $3 \%$ in market value at their M\&A announcements. Consequently, investors form expectations about the surprise announcements based on firms' past M\&A performance and react more negatively to firms with poorer prior M\&A performance. On the other hand, when an acquisition announcement is anticipated, the anticipated profitability of future M\&As has been gradually impounded into the share prices prior to the announcement and the announcement window return is not systematically associated with past M\&A history. Taken together, results on the short-window return test around acquisition announcements are consistent with the anticipation effect and complement earlier findings. Conditioning on acquisitions being announced, stock returns are negatively associated with the history of over-investment for unexpected acquisitions. 


\section{Additional analysis}

\subsection{Likelihood of becoming a target}

Mitchell and Lehn (1990) find that firms that made value-destroying acquisitions ("bad bidders") are more likely to become takeover targets in the five years after these acquisitions. They explain their findings as the market taking a disciplinary role to promote economic efficiency by reallocating resources from value-destroying acquiring firms to higher-valued uses. They interpret takeovers as both a "symptom" of and a "solution" to the over-investment problem. Takeovers are symptoms of over-investment for firms that engage in value-destroying M\&As. Takeovers are also solutions to overinvestment as they allow other firms to acquire the over-investing firms in the future.

The link between the "symptom" and the "solution", however, is not discussed in their study. My findings documented in this paper suggest that the market values of firms with positive free cash flow and histories of over-investment in past M\&As are lower due to investors' expectations of future value-destroying over-investment. At the same time, these firms are generating positive free cash flow. These two conditions make them ideal takeover targets as potential acquirers can obtain control of these cashgenerating enterprises at relatively low prices. To examine if it is indeed the case that firms with positive free cash flow and a history of over-investment are more likely to be acquired, I estimate the following Logit regression.

$$
\text { Acquired }_{i, t}=\alpha+\beta_{1} \text { Incidence }_{i, t}+\beta_{2} \text { Size }_{i, t}+\beta_{3} \text { Leverage }_{i, t}+\beta_{4} B T M_{i, t}+\beta_{5} R O A_{i, t}+u_{i, t}
$$


The dependent variable takes 1 if a firm becomes a takeover target in the next five years. Incidence is the main variable of interest. Size, Leverage, and Positive FCF are defined as above. BTM is the book-to-market ratio. ROA is return on assets, defined as income before extraordinary items scaled by total assets.

Table 8: Bad Bidders Are Taken Over

\begin{tabular}{lccc}
\hline \hline & $(1)$ & $(2)$ & $(3)$ \\
\cline { 2 - 4 } & $\mathrm{FCF}>=0$ & $\mathrm{FCF}<0$ & Full Sample \\
\hline Incidence & $0.922^{* *}$ & 0.0145 & 0.125 \\
& $(2.57)$ & $(0.04)$ & $(0.32)$ \\
Positive FCF & & & -0.178 \\
& & & $(-0.10)$ \\
Positive & & & \\
FCF*Incidence & & & $0.681^{* *}$ \\
& & & $(2.24)$ \\
Size & $-0.216^{* *}$ & -0.0655 & $-0.168^{* *}$ \\
& $(-2.43)$ & $(-0.64)$ & $(-2.21)$ \\
Leverage & 1.115 & $-1.555^{*}$ & 0.180 \\
& $(1.55)$ & $(-1.84)$ & $(0.26)$ \\
BTM & -0.651 & $0.279^{*}$ & -0.164 \\
& $(-1.49)$ & $(1.87)$ & $(-0.57)$ \\
ROA & 1.511 & $1.331^{* * *}$ & 1.411 \\
& $(0.85)$ & $(2.99)$ & $(1.34)$ \\
Intercept & Yes & Yes & Yes \\
N & 3,853 & 2,365 & 6,218 \\
Pseudo R-squared & 0.074 & 0.034 & 0.049 \\
\hline \hline
\end{tabular}

This table reports results from a Logit regression of Acquired on past history and firm characteristics. The dependent variable Acquired takes one if a firm becomes the target in the next four years and zero otherwise. Incidence is weighted average negative performance incidence defined in the main text. Size is the logged total assets. Leverage is the market leverage defined as total debt over the sum of total debt and the market value of equity. BTM is the book-to-market ratio. ROA is return on assets and is defined as net income divided by total assets. Positive FCF is a dummy variable and takes one if the free cash flow measured as in Richardson (2006) is positive and zero otherwise. All standard errors are two-way clustered by both firm and year. Z-statistics are presented underneath the coefficient estimates and ***,**, and * indicate that estimates are significantly different from zero at $1 \%, 5 \%$, and $10 \%$ level, respectively. 
Table 8 presents the Logit regression results. Consistent with my prediction, the coefficient estimate on Incidence is positive and statistically significant in the subsample of positive FCF firms (Column (1)) and insignificant in the subsample of negative FCF firms (Column (2)). When estimated on the entire sample (Column (3)), the coefficient on Positive FCF ${ }^{*}$ Incidence is positive and significant, implying that the combination of both positive free cash flow and a history of value-destroying acquisitions is associated with a higher probability of being acquired in the future. ${ }^{1}$ These results support the argument in Mitchell and Lehn (1990) in that bad acquirers with positive free cash flow are more likely to become takeover targets. Taken together, these results suggest that the anticipation effect documented in the paper provides a link between the "symptom" and the "solution." The combination of both the over-investment history and positive free cash flow gives rise to low firm values through the anticipation effect, which in turn, attracts outsiders to take over the bad bidders in the future.

\subsection{Further analysis using goodwill impairment}

To this point, the independent variable Incidence is measured using one-year post-acquisition abnormal stock returns. This measure assumes that the one-year abnormal return after acquisition completion captures the value consequences of acquisitions. To assess the sensitivity of my main results to this assumption, I also use an alternative accounting-based measure to evaluate past M\&A investment. Specifically, I

\footnotetext{
${ }^{1} \mathrm{Ai}$ and Norton (2003) present the correct way to estimate the magnitude and standard error of the marginal interaction effect in nonlinear models. Untabulated results show that this interaction term is both positive and statistically significant.
} 
use cumulative goodwill write-offs subsequent to M\&As to capture whether a firm has over-invested in past M\&As.

Accounting rules have changed regarding goodwill impairments. In March 1995, the Financial Accounting Standards Board (FASB) issued Statement of Financial Accounting Standards (SFAS) No. 121, “Accounting for the Impairment of Long-Lived Assets," prescribing an impairment test for long-term assets. Firms began to report goodwill write-offs after 1995 when SFAS No. 121 became effective. A subsequent standard, SFAS 142, "Goodwill and Other Intangible Assets," effective since July 2001, eliminates goodwill amortization and specifies the method of computing goodwill impairment loss by estimating the implied fair value of goodwill as a residual asset of the reporting unit. When the goodwill's expected future cash flow is lower than its book value, a firm writes off its goodwill. The impairment charge is reported as an expense in the income statement. Thus, a higher amount of goodwill write-offs indicates overinvestment in previous M\&As. Therefore, I employ the cumulative goodwill write-offs as an alternative independent variable to capture the past history of over-investment. ${ }^{2}$

As I need ten years of data to calculate past history, I repeat the analysis in Table 4 for the post-2006 sample using this accounting-based measure. CGW (Cumulative Goodwill Write-off) is the sum of goodwill impairment reported in Compustat each year over a ten-year rolling window scaled by total assets. If the CGW is higher, a firm is

${ }^{2}$ The use of cumulative goodwill write-offs has several limitations. Recent studies (Hayn and Hughes (2006), Li et al. (2011)) show that managers bias the timing of goodwill impairments and that goodwill write-offs lag behind the economic impairment of goodwill by an average of three to four years. Muller et al. (2012) provide empirical evidence that corporate insiders benefit from delayed goodwill impairments through abnormal selling of shares. 
more likely to have overpaid for targets in previous acquisitions. Similar to equation [4], I hypothesize that for firms with positive free cash flow, CGW is negatively associated with Tobin's $Q$.

Table 9: Post-2006 Firm Value Test Using Goodwill Impairment

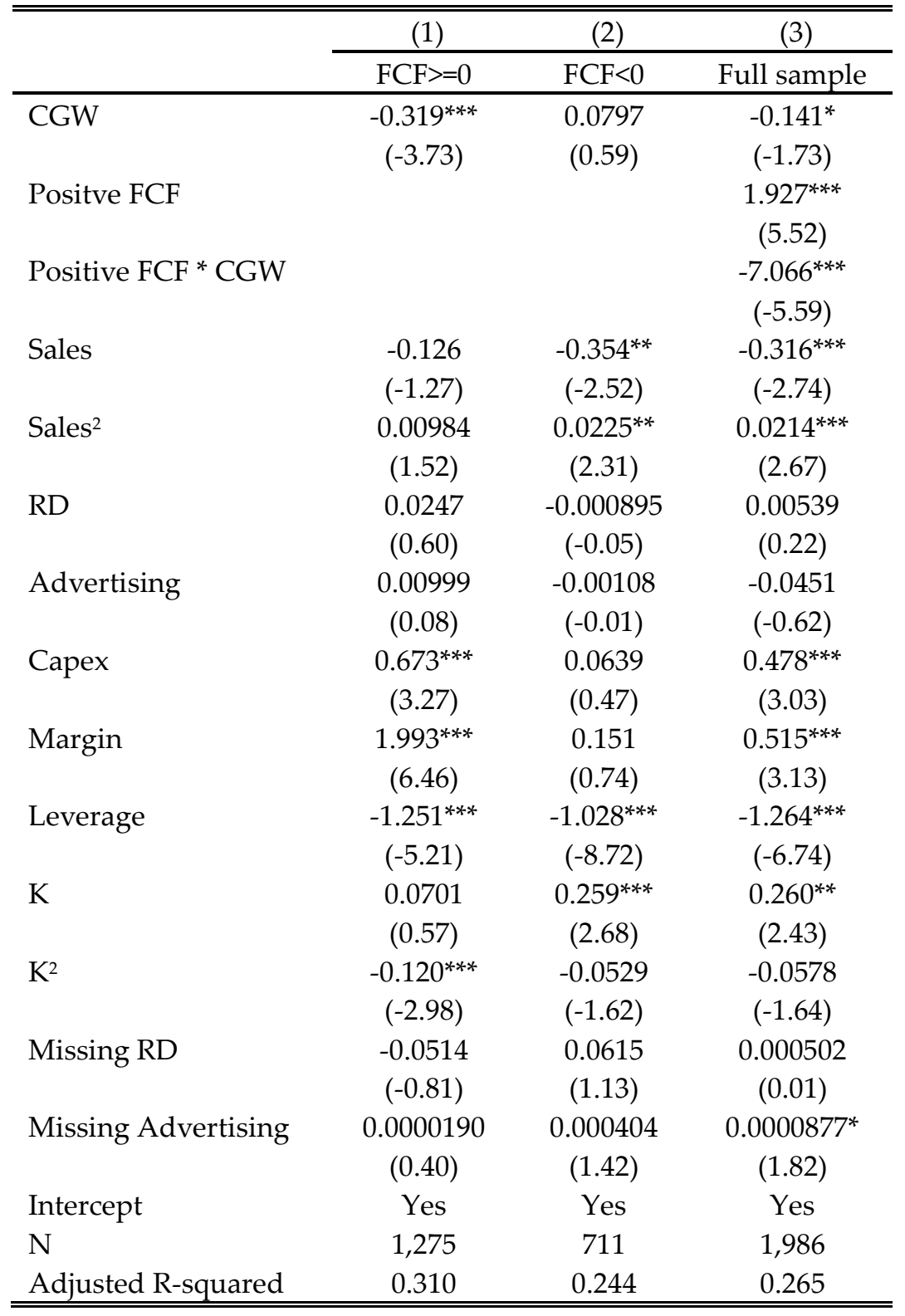

This table reports results from an OLS regression of Tobin's Q on past cumulative goodwill write-off in addition to firm characteristics. Tobin's $Q$ is the sum of market value of equity, liquidation value of 
preferred equity and book value of total liabilities scaled by total assets. Incidence is weighted average negative performance incidence defined in the main text. Sales is logged annual sales number. RD is annual research and development expenditure scaled by PPE. Advertising is annual advertising expense scaled by PPE. Capex is annual capital expenditure scaled PPE. Margin is the ratio of operating income before depreciation to sales. Leverage is the market leverage defined as total debt over the sum of total debt and the market value of equity. $\mathrm{K}$ is property, plant, and equipment scaled by sales. Missing RD (Missing Advertising) takes one if the annual RD (Advertising) is missing and zero otherwise. CGW is sum of goodwill write-off over the past ten years scaled by total assets. Positive FCF is a dummy variable and takes one if the free cash flow measured as in Richardson (2006) is positive and zero otherwise. All standard errors are two-way clustered by both firm and year. T-statistics are presented underneath the coefficient estimates and $* *, * *$, and $*$ indicate that estimates are significantly different from zero at $1 \%, 5 \%$, and $10 \%$ level, respectively.

Table 9 presents the OLS regression results using a subsample of post-2006 firm-year observations. As predicted, CGW is negatively and statistically significantly associated Tobin's $Q$ in the positive FCF sample, but is statistically insignificant in the negative FCF sample. When the regression is estimated on the full sample in Column (3), the interaction between Positive FCF and CGW is negative and statistically significant. These results confirm findings that over-investment history affects future firm value through the anticipation channel.

\subsection{Robustness Checks}

In this section, I provide several robustness checks to my main empirical design. These additional analyses help understand the main research question that I discuss in this paper.

\subsubsection{Use analysts' forecasted price to calculate Tobin's Q}

In the main analysis, I use Tobin's $Q$ as the proxy for firm value, whereas Tobin's

$\mathrm{Q}$ is based on the observed stock price. An alternative approach to examine investors' expectations is to use analysts' forecasted price targets. The key difference between my 
design and the design using analysts' forecasted price targets is whether investors, rather than analysts, have incorporated their anticipation of future acquisitions into the share price determination. In addition, the design using analysts' forecasted price target sheds no direct light on whether the market is efficient in forming expectations about the profitability of future acquisitions. Therefore, the design using analysts' forecasted price targets is indirect to the examination whether the observed market prices embed investors' expectation. In this robustness check, I conduct an analysis using a subsample with analyst coverage. I use analysts' forecasted price targets to calculate the expected Tobin's $Q$ and present the main result below. Expected Tobin's $Q$ is calculated as sum of expected market value of equity (the number of shares outstanding times the forecasted price target), liquidation value of preferred equity, and book value of total liabilities, scaled by the book value of total assets. Results are presented in Table 10.1. Inferences are very similar to the discussion for Table 4. Specifically, the coefficient on Incidence is negative and statistically significant only for the positive FCF sample, consistent with H1.

Table 10.1: Robustness check using analysts' forecasted price

\begin{tabular}{lccc}
\hline \hline & $(1)$ & \multicolumn{2}{c}{$(2)$} \\
\cline { 2 - 4 } Tobin's Q & \multicolumn{3}{c}{ Use price target } \\
\cline { 2 - 4 } Incidence & $\mathrm{FCF}>=0$ & $\mathrm{FCF}<0$ & Full sample \\
\hline \multirow{2}{*}{ Positive FCF } & $-0.209^{* * *}$ & -0.0772 & -0.0425 \\
& $(-3.88)$ & $(-1.23)$ & $(-0.58)$ \\
Positive FCF* Incidence & & & $0.274^{* * *}$ \\
& & & $(3.56)$ \\
Control variables & & & $-0.187^{*}$ \\
$\mathrm{~N}$ & Included & Included & $(-1.93)$ \\
& 2,586 & 1,206 & included \\
\hline \hline
\end{tabular}


Incidence is the weighted average negative performance incidence defined the same as in Table 4. Tobin's Q is the expected Tobin's $Q$ defined as the sum of expected market value of equity (the number of shares outstanding times the forecasted price target), liquidation value of preferred equity, and book value of total liabilities, scaled by the book value of total assets. Control variables are defined similarly as in Table 4 and are included but not reported. T-statistics are presented underneath the coefficient estimates and ${ }^{* *},{ }^{* *}$, and

* indicate that estimates are significantly different from zero at $1 \%, 5 \%$, and $10 \%$ level, respectively.

\subsubsection{Use alternative definitions to calculate BHCAR}

In the main analysis, I calculate $B H C A R$ using the post-completion one-year stock return to classify acquisitions as value-creating or value-destroying. Alternatively, I calculate BHCAR from the announcement date and classify past acquisitions as valuecreating and value-destroying ones accordingly. Specifically, in the robustness check below, I calculate BHCAR as the one-year return compounded from the announcement dates of acquisitions. Results are presented in Table 10.2, Panel A and inferences are consistent with my main hypothesis.

Table 10.2: Robustness check Using Alternative BHCAR definitions

Panel A: BHCAR defined as post-announcement one-year return

\begin{tabular}{lccc}
\hline \hline & \multicolumn{2}{c}{$(1)$} & $(2)$ \\
\cline { 2 - 4 } Tobin's Q & \multicolumn{2}{c}{ Use BHCAR calculated as post-announcement one-year return } \\
\cline { 2 - 4 } & $\mathrm{FCF}>=0$ & $\mathrm{FCF}<0$ & Full sample \\
\hline Incidence & $-0.249^{* * *}$ & -0.0677 & -0.0285 \\
& $(-4.32)$ & $(-1.38)$ & $(-0.51)$ \\
Positive FCF & & & $0.290^{* * *}$ \\
& & & $(4.36)$ \\
Positive FCF* Incidence & & & $-0.269^{* * *}$ \\
& & & $(-3.01)$ \\
Control variables & included & included & Included \\
$\mathrm{N}$ & 3,853 & 2,365 & 6,218 \\
\hline \hline
\end{tabular}

Incidence is the weighted average negative performance incidence measured using BHCAR based on postannouncement one-year return. Control variables are defined similarly as in Table 4 and are included but 
not reported. T-statistics are presented underneath the coefficient estimates and ${ }^{* *}, * *$, and ${ }^{*}$ indicate that estimates are significantly different from zero at $1 \%, 5 \%$, and $10 \%$ level, respectively.

In the main analysis, I use one-year BHCAR after the acquisition deals to designate acquisitions as profitable or unprofitable. In the robustness check below, I present results using alternative windows to calculate BHCAR and Incidence. Specifically, BHCAR is defined as the compounded 6-month and 9-month return after the acquisition completion date, respectively. Incidence is defined similarly as before using this new definition of BHCAR. The variables of interest are Incidence and the positive FCF ${ }^{*}$ Incidence. Results are presented in Table 10.2 Panel B. Across both alternative definitions of Incidence, the coefficient on Incidence is negative and statistically significant only on the positive FCF sample. When the equation is estimated over the entire sample, the coefficient on positive FCF ${ }^{*}$ Incidence is negative and statistically significant, consistent with H1.

Panel B: BHCAR defined as other alternative post-completion return

\begin{tabular}{|c|c|c|c|c|c|c|}
\hline \multirow[b]{3}{*}{ Tobin's Q } & $(1)$ & $(2)$ & $(3)$ & $(4)$ & $(5)$ & $(6)$ \\
\hline & \multicolumn{3}{|c|}{ 6-month BHCAR } & \multicolumn{3}{|c|}{ 9-month BHCAR } \\
\hline & $\mathrm{FCF}>=0$ & $\mathrm{FCF}<0$ & $\begin{array}{c}\text { Full } \\
\text { sample }\end{array}$ & $\mathrm{FCF}>=0$ & $\mathrm{FCF}<0$ & $\begin{array}{c}\text { Full } \\
\text { sample }\end{array}$ \\
\hline Incidence & $\begin{array}{l}-0.116^{* *} \\
(-2.30)\end{array}$ & $\begin{array}{l}-0.0786 \\
(-1.59)\end{array}$ & $\begin{array}{l}-0.0277 \\
(-0.53)\end{array}$ & $\begin{array}{c}-0.207^{* * *} \\
(-3.89)\end{array}$ & $\begin{array}{l}-0.0635 \\
(-1.29)\end{array}$ & $\begin{array}{l}-0.0312 \\
(-0.56)\end{array}$ \\
\hline Positive FCF & & & $\begin{array}{c}0.213^{* * *} \\
(4.01)\end{array}$ & & & $\begin{array}{c}0.257^{* * *} \\
(4.09)\end{array}$ \\
\hline Positive $\mathrm{FCF}^{*}$ Incidence & & & $\begin{array}{l}-0.141^{*} \\
(-1.90)\end{array}$ & & & $\begin{array}{c}-0.210^{* * *} \\
(-2.67)\end{array}$ \\
\hline $\begin{array}{l}\text { Control variables } \\
\mathrm{N}\end{array}$ & $\begin{array}{c}\text { included } \\
3,853\end{array}$ & $\begin{array}{c}\text { included } \\
2,365 \\
\end{array}$ & $\begin{array}{c}\text { included } \\
6,218\end{array}$ & $\begin{array}{c}\text { included } \\
3,853 \\
\end{array}$ & $\begin{array}{c}\text { included } \\
2,365 \\
\end{array}$ & $\begin{array}{c}\text { included } \\
6,218\end{array}$ \\
\hline
\end{tabular}

Incidence is the weighted average negative performance incidence measured using BHCAR based on postcompletion 6-month and 9-month return, respectively. Control variables are defined similarly as in Table 4 
and are included but not reported. T-statistics are presented underneath the coefficient estimates and ${ }^{* * *}, * *$, and ${ }^{*}$ indicate that estimates are significantly different from zero at $1 \%, 5 \%$, and $10 \%$ level, respectively.

\subsubsection{Use alternative definitions to calculate Incidence}

In the main text, I use the sign of BHCAR to classify past acquisitions into valuecreating and value-destroying ones. In other words, I use information only about the sign of $B H C A R$, and weight the sign of $B H C A R$ to account for recency effect. In the robustness check below, I utilize the actual magnitude of BHCAR and define Incidence $e^{B H C A R}$ as the negative of the weighted average of BHCAR with the weight being ten minus distance in time. As before, under this definition, higher Incidence maps into worse acquisition history.

I first provide the summary statistics for BHCAR in Table 10.3, Panel A. The mean of $B H C A R$ is negative at -0.015 and is statistically different from zero at $10 \%$ level (t-test). The median of BHCAR is negative at -0.056 and is statistically different from zero at the $1 \%$ level (Wilcoxon test). These results are very similar to a recent study by Erikson et al. (2012).

I repeat the main analysis and report results based on Incidence ${ }^{B H C A R}$ in Table 10.3, Panel B. It is clear that, the coefficient on Incidence ${ }^{B H C A R}$ is negative and statistically significant only for the positive FCF (likely acquirer) sample. When the regression is estimated on the full sample in Column (3), the interaction between Positive FCF and Incidence is negative and statistically significant $(\beta=-0.332, t$-statistic $=-4.08)$, emphasizing that it is the combination of both anticipated likelihood and the over-investment history 
that matter in the firm value discount.

As another robustness check, I use the actual magnitudes of the deals as weights.

As opposed to using distance in time as weights in the main analysis, Columns (1) to (3)

use the raw deal sizes as weights to account for cross-sectional differences in deal size. I

present the results in Table 10.3, Panel C. To summarize, results are similar to the reported results in Table 4 in all aspects.

Table 10.3: Robustness check Using Alternative Incidence definitions

Panel A: Summary Statistics for BHCAR

\begin{tabular}{ccccccc}
\hline \hline Variable & Mean & P10 & P25 & Median & P75 & P90 \\
\hline BHCAR & $-0.015^{*}$ & -0.512 & -0.285 & $-0.056^{* * *}$ & 0.162 & 0.454 \\
T-/Z-statistics & $(-1.68)$ & & & $(-9.10)$ & & \\
\hline \hline
\end{tabular}

This panel reports the summary statistics of buy-and-hold cumulative abnormal return (BHCAR) for each acquisition. BHCAR is defined as the one-year abnormal returns adjusted by the Fama-French $(1992,1993)$ $5^{*} 5$ size and book-to-market benchmark portfolios. Control variables are defined similarly as in Table 4 and are included but not reported. T-statistics (Z-statistics) for the mean (median) are presented in the parenthesis and ${ }^{* * *},{ }^{* *}$, and ${ }^{*}$ indicate that estimates are significantly different from zero at $1 \%, 5 \%$, and $10 \%$ level, respectively.

Panel B: Results using Incidence $e^{\text {BHCAR }}$

\begin{tabular}{|c|c|c|c|}
\hline \multirow[b]{3}{*}{ Tobin's Q } & $(1)$ & $(2)$ & $(3)$ \\
\hline & \multicolumn{3}{|c|}{ Incidence defined as the negative of weighted average $B H C A R$} \\
\hline & $\mathrm{FCF}>=0$ & $\mathrm{FCF}<0$ & Full sample \\
\hline Incidence $e^{B H C A R}$ & $\begin{array}{c}-0.315^{* * *} \\
(-5.51)\end{array}$ & $\begin{array}{c}-0.0604 \\
(-1.28)\end{array}$ & $\begin{array}{c}-0.0256 \\
(-0.48)\end{array}$ \\
\hline Positive FCF & & & $\begin{array}{c}0.145^{* * *} \\
(4.47)\end{array}$ \\
\hline Positive $\mathrm{FCF}^{*}$ Incidence & & & $\begin{array}{c}-0.332^{* * *} \\
(-4.08)\end{array}$ \\
\hline Control variables & included & included & included \\
\hline $\mathrm{N}$ & 3,853 & 2,365 & 6,218 \\
\hline
\end{tabular}


Incidence is the weighted average negative BHCAR. Control variables are defined similarly as in Table 4 and are included but not reported. T-statistics are presented underneath the coefficient estimates and ${ }^{* * *},{ }^{* *}$, and * indicate that estimates are significantly different from zero at 1\%,5\%, and 10\% level, respectively.

Panel C: Results using alternative weighting schemes

\begin{tabular}{lccc}
\hline \hline & \multicolumn{2}{c}{$(1)$} & $(3)$ \\
\cline { 2 - 4 } Tobin's Q & \multicolumn{2}{c}{ Incidence: deal-sized weighted } \\
\cline { 2 - 4 } & $\mathrm{FCF}>=0$ & $\mathrm{FCF}<0$ & Full sample \\
\hline Incidence & $-0.163^{* * *}$ & -0.0119 & 0.0529 \\
& $(-3.15)$ & $(-0.27)$ & $(1.01)$ \\
Positive FCF & & & $0.287^{* * *}$ \\
& & & $(5.48)$ \\
Positive FCF* Incidence & & & $-0.267^{* * *}$ \\
& & & $(-3.42)$ \\
Control variables & included & included & included \\
$\mathrm{N}$ & 3,853 & 2,365 & 6,218 \\
\hline \hline
\end{tabular}

Incidence is the weighted average negative performance incidence defined in the main text, whereas weights are deal transaction values. Control variables are defined similarly as in Table 4 and are included but not reported. T-statistics are presented underneath the coefficient estimates and ${ }^{* * *},{ }^{*}$, and ${ }^{*}$ indicate that estimates are significantly different from zero at 1\%,5\%, and $10 \%$ level, respectively.

\subsubsection{Use alternative Definitions to Classify Acquisitions}

In my main design, I use the post-acquisition stock performance as the metric to assess past acquisitions' profitability. In other words, this design uses a market-based measure to assess past acquisitions' performance and then uses that as an expected profitability proxy to examine a market-based firm value measure, Tobin's $Q$. Therefore, in the main examination, the dependent variable (Tobin's $Q$ ) and the independent variable (Incidence) are both market-based measures, keeping the conceptual consistency of shareholder values. Alternatively, in this section, I employ a fundamental-based measure to assess past acquisitions' profitability. Specifically, I compare the acquirer's ROA in the years before and after the acquisition. If the acquirer's shareholders 
experience an increase (decrease) after the acquisition, that acquisition is designated as value-creating (value-destroying). Incidence is then defined similarly as before using this ROA-based measure. I present the results using this ROA-based measure in the table blow.

Table 10.4: Robustness check using ROA to classify acquisition performance

\begin{tabular}{lccc}
\hline \hline & \multicolumn{2}{c}{$(1)$} & $(3)$ \\
\cline { 2 - 4 } Tobin's Q & \multicolumn{2}{c}{ Incidence } & defined based on ROA \\
\cline { 2 - 4 } & $\mathrm{FCF}>=0$ & $\mathrm{FCF}<0$ & Full sample \\
\hline Incidence & $-0.131^{* *}$ & -0.00271 & -0.0162 \\
& $(-2.06)$ & $(-0.07)$ & $(-0.35)$ \\
Positive FCF & & & $0.225^{* * *}$ \\
& & & $(4.11)$ \\
Positive FCF* Incidence & & & $-0.149^{* *}$ \\
& & & $(-2.02)$ \\
Control variables & included & included & included \\
$\mathrm{N}$ & 3,853 & 2,365 & 6,218 \\
\hline \hline
\end{tabular}

Incidence is the weighted average negative performance incidence defined in the main text. An acquisition is classified as value-creating (value-destroying) one if the acquirer's shareholders experience an increase (decrease) after the acquisition. Control variables are defined similarly as in Table 4 and are included but not reported. T-statistics are presented underneath the coefficient estimates and ${ }^{* * *},{ }^{* *}$, and ${ }^{*}$ indicate that estimates are significantly different from zero at $1 \%, 5 \%$, and $10 \%$ level, respectively.

The coefficient on Incidence is negative and statistically significant only for the positive FCF sample. When the regression is estimated on the full sample in Column (3), the interaction between Positive FCF and Incidence is negative and statistically significant at $5 \%$ level $(\beta=-0.149, t$-statistic $=-2.02)$, emphasizing again that it is the combination of both anticipated likelihood and the over-investment history that matter in the firm value discount. 
5.3.5 Use alternative definitions to classify likely and unlikely acquirers

In the main analysis, I use free cash flow $(F C F)$ to designate firms into likely acquirers and unlikely acquirers. This designation is consistent with Jensen's (1986) free cash flow hypothesis as well as Richardson's (2006) findings that firms with positive free cash flow are likely to overinvest. More importantly, firms with positive free cash flow have both the tendency and ability to invest in future acquisitions. Cash flows generated internally are less likely to subject to the monitoring of equity and debt holders and are more likely to be overinvested.

An alternative way to classify firms into likely acquirers and unlikely acquirers is to use the predicted probability of acquisitions from equation [3]. In the following robustness analysis, I classify firms into likely (unlikely) acquirers using the predicted value from equation [3]. Specifically, the variable Likely takes a value of one (zero) if the predicted value from equation [3] is higher (lower) than the median. I present the results in Table 10.5, Panel A. In general, results are consistent with the anticipation hypothesis $\mathrm{H} 1$ and robust to the choice variable to classify firms into likely and unlikely acquirers.

Table 10.5: Robustness check using alternative ways to classify likely and unlikely acquirers Panel A: Results using the predicted probability to classify likely and unlikely acquirers

\begin{tabular}{lccc}
\hline \hline & $(1)$ & $(2)$ & $(3)$ \\
\cline { 2 - 4 } Tobin's Q & \multicolumn{2}{c}{ Alternative } & way to classify acquirers \\
\cline { 2 - 4 } Likely=1 & Likely=0 & Full sample \\
\hline Incidence & $-0.200^{* * *}$ & 0.0585 & 0.0545 \\
& $(-2.75)$ & $(0.56)$ & $(0.52)$ \\
Likely & & & $0.418^{* * *}$
\end{tabular}




\begin{tabular}{lccc} 
Likely* Incidence & & & $-0.288^{* *}$ \\
& & & $(-2.06)$ \\
Control variables & included & included & Included \\
$\mathrm{N}$ & 3,853 & 2,365 & 6,218 \\
\hline \hline
\end{tabular}

Incidence is the weighted average negative performance incidence defined the same as in Table 4 . The variable Likely takes a value of one (zero) if the predicted value from equation [3] is higher (lower) than the median. Control variables are defined similarly as in Table 4 and are included but not reported. T-statistics are presented underneath the coefficient estimates and ${ }^{* *},{ }^{* *}$, and ${ }^{*}$ indicate that estimates are significantly different from zero at $1 \%, 5 \%$, and $10 \%$ level, respectively.

Another alternative way to classify firms into likely and unlikely acquirers is to use multiple-year FCF measures, following the idea that a firm with multiple years of positive FCF is more likely to have the financial means to make acquisitions. I first provide the results of an $\mathrm{AR}(1)$ process estimated over the entire Compustat universe as follows:

$$
\begin{gathered}
F C F_{i, t}=\alpha+\beta F C F_{i, t-1} \\
-0.0060 .603
\end{gathered}
$$

The coefficient estimates for $\alpha$ and $\beta$ are -0.006 and 0.603 , respectively. The $\mathrm{t}-$ statistics are presented in parentheses. The above result shows that free cash flow is time-series persistent with an $\mathrm{AR}(1)$ parameter of 0.603 . In the following robustness analysis, I classify firms into likely (unlikely) acquirers using the sum of their current and previous year's FCF. Specifically, the variable Positive FCF takes a value of one (zero) if the sum of a firm's current and previous year FCF is positive (negative). Results are presented in Table 10.5, Panel B and are consistent with the anticipation hypothesis. 
Panel B: Results using multiple-years FCF measures to classify likely and unlikely acquirer

\begin{tabular}{lccc}
\hline \hline & \multicolumn{2}{c}{$(1)$} & $(2)$ \\
\cline { 2 - 4 } Tobin's Q & \multicolumn{2}{c}{ FCF defined as consecutive two-year sum of FCF } \\
\cline { 2 - 4 } Incidence & FCF $>=0$ & FCF $<0$ & Full sample \\
& $(-3.50)$ & -0.00818 & 0.0583 \\
Positive FCF & & & $(1.00)$ \\
& & $0.307^{* * * *}$ \\
Positive FCF* & & $(5.03)$ \\
Incidence & & & $-0.301^{* * *}$ \\
& & & $(-3.37)$ \\
Control variables & included & included & included \\
$\mathrm{N}$ & 3,853 & 2,365 & 6,218 \\
\hline \hline
\end{tabular}

Incidence is the weighted average negative performance incidence defined the same as in Table 4. Positive FCF takes a value of one (zero) if the sum of a firm's current and previous year FCF is positive (negative). Control variables are defined similarly as in Table 4 and are included but not reported. T-statistics are presented underneath the coefficient estimates and ${ }^{* *},{ }^{* *}$, and ${ }^{*}$ indicate that estimates are significantly different from zero at $1 \%, 5 \%$, and $10 \%$ level, respectively.

\subsubsection{Use alternative benchmarks to subset prior acquisitions}

In the main text, I calculate a firm's past M\&A history based on historical acquisitions that are at least partially cash financed, i.e., the cash payment accounts for at least $1 \%$ of the transaction value. This requirement enables my independent variable Incidence to measure how the firm spends cash in previous acquisitions. In contrast, acquisitions completely financed using shares are less representative about how the firm deals with free cash and are not employed as inputs to calculate Incidence. In the robustness checks below, I use alternative benchmarks to this $1 \%$ cash payment requirement. Specifically, I require cash payment portions larger than $5 \%$ and $10 \%$ of the 
transaction value, respectively. Results are presented in Table 10.6 and inferences are similar to the discussion in the main analysis.

Table 10.6: Robustness check using alternative benchmarks to subset prior acquisitions

\begin{tabular}{|c|c|c|c|c|c|c|}
\hline \multirow[b]{3}{*}{ Tobin's Q } & $(1)$ & $(2)$ & $(3)$ & $(4)$ & $(5)$ & $(6)$ \\
\hline & \multicolumn{3}{|c|}{ Cash payment $>=5 \%$} & \multicolumn{3}{|c|}{ Cash payment $>=10 \%$} \\
\hline & $\mathrm{FCF}>=0$ & $\mathrm{FCF}<0$ & $\begin{array}{c}\text { Full } \\
\text { sample }\end{array}$ & $\mathrm{FCF}>=0$ & $\mathrm{FCF}<0$ & $\begin{array}{c}\text { Full } \\
\text { sample }\end{array}$ \\
\hline Incidence & $\begin{array}{c}-0.180^{* * *} \\
(-3.42)\end{array}$ & $\begin{array}{c}-0.000719 \\
(-0.02)\end{array}$ & $\begin{array}{l}0.0656 \\
(1.18)\end{array}$ & $\begin{array}{c}-0.193^{* * * *} \\
(-3.71)\end{array}$ & $\begin{array}{c}-0.00534 \\
(-0.11)\end{array}$ & $\begin{array}{l}0.0563 \\
(0.97)\end{array}$ \\
\hline Positive FCF & & & $\begin{array}{l}0.307^{* * *} \\
(5.23)\end{array}$ & & & $\begin{array}{c}0.310^{* * *} \\
(5.05)\end{array}$ \\
\hline \multicolumn{7}{|l|}{ Positive $\mathrm{FCF}^{*}$} \\
\hline Incidence & & & $\begin{array}{c}-0.298^{* * *} \\
(-3.61)\end{array}$ & & & $\begin{array}{c}-0.306^{* * *} \\
(-3.73)\end{array}$ \\
\hline $\begin{array}{l}\text { Control variables } \\
\mathrm{N}\end{array}$ & $\begin{array}{c}\text { included } \\
3,827\end{array}$ & $\begin{array}{c}\text { included } \\
2,328\end{array}$ & $\begin{array}{c}\text { included } \\
6,155\end{array}$ & $\begin{array}{c}\text { included } \\
3,777\end{array}$ & $\begin{array}{c}\text { included } \\
2,290\end{array}$ & $\begin{array}{c}\text { included } \\
6,067\end{array}$ \\
\hline
\end{tabular}

Incidence is the weighted average negative performance incidence defined the same as in Table 4. Control variables are defined similarly as in Table 4 and are included but not reported. T-statistics are presented underneath the coefficient estimates and ${ }^{* * *},{ }^{* *}$, and ${ }^{*}$ indicate that estimates are significantly different from zero at $1 \%, 5 \%$, and $10 \%$ level, respectively.

\subsubsection{An examination of firms making multiple acquisitions}

In the main analysis, to calculate a firm's acquisition history, I require a firm to have at least one acquisition in the past ten years. In this robustness check, I include only firms with multiple (more than once) acquisitions in the past. I present the results in Table 10.7. First of all, results are generally consistent with my hypothesis that firm values are negatively associated with the incidence of past value-destroying M\&As when firms have positive free cash flow. More importantly, Table 10.7 shows that on average, among firms with positive free cash flow, firm value decreases by 0.342 when 
moving from firms with the best history (Incidence=0) to firms with the worst history (Incidence=1). In Table 4, Panel A of the main text, when I estimate the main equation on a sample of firms with at least one acquisition, the coefficient on Incidence is -0.179 . The difference between the baseline sample and the multiple-acquisition sample suggests that the anticipation discount is more severe for firms with multiple acquisitions in the past. Hypothetically speaking, for two firms with identical Incidence but different times of acquisitions in the past, investors place a higher discount on the one with more valuedestroying acquisitions.

Table 10.7: Results for firms with multiple acquisitions in the past

\begin{tabular}{lccc}
\hline \hline & \multicolumn{2}{c}{$(1)$} & $(3)$ \\
\cline { 2 - 4 } Tobin's Q & \multicolumn{3}{c}{ Multiple-acquisition sample } \\
\cline { 2 - 4 } Incidence & $\mathrm{FCF}>=0$ & $\mathrm{FCF}<0$ & Full sample \\
& $-0.342^{* * *}$ & -0.0207 & 0.0781 \\
Positive FCF & $(-3.10)$ & $(-0.15)$ & $(0.59)$ \\
& & & $0.285^{* *}$ \\
Positive FCF* Incidence & & & $(2.53)$ \\
& & & $-0.450^{* *}$ \\
Control variables & & & $(-2.47)$ \\
$\mathrm{N}$ & included & included & included \\
& 785 & 415 & 1,200 \\
\hline \hline
\end{tabular}

Incidence is the weighted average negative performance incidence defined the same as in Table 4 . Control variables are defined similarly as in Table 4 and are included but not reported. T-statistics are presented underneath the coefficient estimates and ${ }^{* *},{ }^{* *}$, and ${ }^{*}$ indicate that estimates are significantly different from zero at $1 \%, 5 \%$, and $10 \%$ level, respectively.

Taken together, these additional robustness examinations provide supporting evidence to my main hypothesis that investors assess an anticipation discount for firms with value-destroying acquisitions. 


\section{Conclusion}

I examine the long-term valuation consequence of over-investment on acquiring firms through the "anticipation effect," in which forward-looking firm values contain information about possible upcoming M\&As.

I find that for firms with positive free cash flow, those with the worst history of value-destroying M\&As experience a reduction of $10 \%$ in firm value measured in Tobin's Q. In contrast, firms with histories of value-destroying M\&As but negative free cash flow do not experience significant decreases in firm values. These results are consistent with the idea that market valuations of firms with histories of M\&A activities depend on both whether their past M\&As are value-destroying or value-enhancing and whether these firms have positive free cash flow. In addition, I find that a significant portion of the discount is from investors' discounting of cash holdings, consistent with investors expecting that cash will be invested sub-optimally when firms have engaged in more value-destroying M\&As.

This paper contributes to the literature in several ways by studying the economic consequences of acquiring firms' past M\&A activities through the anticipation channel. First, this paper provides evidence on the long-term implications of firms' investment strategies. I show that market valuations embed information about future investments based on past investment outcomes through anticipation. Second, my findings shed light on the underlying mechanism for takeovers to function in a disciplinary role. Third, this paper adds empirical evidence to the literature examining the value of corporate 
cash holdings. I show that the anticipated outcome of cash investment is directly related to investors' valuation of marginal cash holdings. 


\section{References}

Ai, C., Norton, E., (2003). Interaction terms in Logit and Profit models. Economics Letters, 80, 123-129.

Andrade, G., Mitchell, M., Stafford, E. (2001). New evidence and perspectives on mergers. Journal of Economic Perspectives, 15, 103-120.

Alti, A. (2003). How sensitive is investment to cash flow when financing is frictionless. Journal of Finance, 58, 707-722.

Bebchuk, L., Coates, J., Subramanian, G. (2009). The power of takeover defenses. Review of Financial Studies, 22, 783-827.

Biddle, G., Hilary, G., Verdi, R. (2009). How does financial reporting quality relate to investment Efficiency? Journal of Accounting and Economics, 48, 112-131.

Bouwman, C., Fuller, K. Nain, A. (2009). Market valuation and acquisition quality: empirical evidence. Review of Financial Studies, 22, 633-679.

Cai, J., Song, M., Walkling, R. (2011) Anticipation, acquisitions and bidder returns: industry shocks and the transfer of information across rivals. Review of Financial Studies, $25,1-44$.

Cremers, M., John, K., Nair, V. (2009) Takeovers and the cross-section of Returns, Review of Financial Studies, 22, 1409-1445.

Edmans, A., Goldstein, I., Jiang, W. (2012). The real effects of financial markets: The impact of prices on takeovers. Journal of Finance, 67, 933-971.

Erickson, M., Wang, S., Zhang, F.X. (2012). The change in information uncertainty and acquirer wealth losses, Review of Accounting Studies, 17, 913-943.

Fama, E., French, K. (1992). The cross-section of expected stock returns. Journal of Finance, $47,427-465$.

Fama, E., French, K. (1993). Common risk factors in the returns on stocks and bonds. Journal of Financial Economics, 33, 3-56.

Fama, E., French, K. (1997). Industry costs of equity. Journal of Financial Economics, 43, 153-193. 
Faulkender, M., and R. Wang. (2006). Corporate financial policy and the value of cash. Journal of Finance, 61, 1957-1990.

Francis, J., R. LaFond, P. Olsson, and K. Schipper, (2005). The market pricing of accruals quality. Journal of Accounting and Economics, 39, 295-327.

Gompers, P., Ishii, J., Metrick, A. (2003). Corporate governance and equity prices. Quarterly Journal of Economics, 118, 107-155.

Habib, M., Ljungqvist, A., (2005). Firm value and managerial incentives: A stochastic frontier approach. Journal of Business, 78, 2053-2094.

Harford, J. (1999). Corporate cash reserves and acquisitions. Journal of Finance, 54, 19691997.

Harford, J., Li, K. (2007). Decoupling CEO wealth and firm performance: The case of acquiring CEOs. Journal of Finance, 62, 917-949.

Hayashi, F. (1982). Tobin's Marginal q and Average q: a neoclassical Interpretation. Econometrica, 50, 213-224.

Hayn, C., Hughes, P. (2006). Leading indicators of goodwill impairment. Journal of Accounting, Auditing and Finance, 21, 223-265.

Himmelberg, C., Hubbard, R., Palia, D. (1999). Understanding the determinants of managerial ownership and the link between ownership and performance. Journal of Financial Economics 53, 353-384.

Jensen, M. (1986). Agency costs and free cash flow, corporate finance and takeovers. American Economic Review, 76, 659-665.

Kaplan. S., Minton, B. (2012). How has CEO turnover changed? International Review of Finance, 57-87.

Lang, L. H. P., Stulz, R. M., \& Walkling, R. A. (1991). A test of the free cash flow hypothesis: The case of bidder returns. Journal of Financial Economics, 29, 315-335.

Lehn, K. Zhao, M. (2006). CEO turnovers after acquisitions: are bad bidders get fired? Journal of Finance, 1759-1811.

Lehavy. R., Li, F., Merkley, K. (2011). The effect of annual report readability on analyst following and the properties of their earnings forecasts. The Accounting Review, 86, 10871115 . 
Li, Z., Shroff, P., Venkataraman, R. Zhang, I. (2011). Causes and consequences of goodwill impairment losses. Review of Accounting Studies, 745-778.

Malmendier, U., Tate, G. (2008) Who makes acquisitions? CEO overconfidence and the market's reaction. Journal of Financial Economics, 89, 20-43.

Masulis, R., Wang, C. Xie, F., (2007). Corporate governance and acquirer returns. Journal of Finance, 62, 1851-1899.

Mitchell, M. Lehn, K. (1990). Do bad bidders become good targets? Journal of Political Economy, 98, 372-398.

Muller, K., Neamtiu, M., Riedl, E. (2012). Do managers benefit from delay goodwill impairments? Working paper, Pennsylvania State University.

Myers, S., Majluf, R. (1984). Corporate financing and investment decisions when firms have information that investors do not have. Journal of Financial Economics, 13, 187-221.

Myers, S., Rajan, R. (1998). The paradox of liquidity. Quarterly Journal of Economics, 113, 733-771.

Ohlson, J. (1995). Earnings, book values and dividends in security valuation. Contemporary Accounting Research, 11, 661-687.

Opler, T., Pinkowitz, L., Stulz, R., \& Williamson, R. (1999). The determinants and implications of corporate cash holdings. Journal of Financial Economics, 52, 3-46.

Petersen, M. (2009). Estimating standard errors in finance panel data sets: comparing approaches. Review of Financial Studies, 22, 435-480.

Pastor, L., Veronesi, P. (2003). Stock valuation and learning about profitability. Journal of Finance, 58, 1749-1789.

Rau, R., \& Vermaelen, T. (1998). Glamour, value and the post-acquisition performance of acquiring firms. Journal of Financial Economics, 49, 223-253.

Richardson, S. (2006). Over-investment of free cash flow. Review of Accounting Studies, 11, 159-189.

Song, M., Walkling, R. (2000). Abnormal returns to rivals of acquisition targets: A test of the "acquisition probability hypothesis." Journal of Financial Economics, 55, 143-171.

Tobin, J. (1969). A general equilibrium approach to monetary theory. Journal of Money Credit and Banking, 1, 15-29. 
Wang, J. (1993). A model of intertemporal asset prices under asymmetric information. Review of Economic Studies, 60, 249-282. 


\section{Biography}

Ning Zhang earned his bachelor's degree from Tsinghua University and a master's degree in economics from the State University of New York at Binghamton. He is interested in the role of information and incentives in financial markets as well as in firm investment decisions. 